\title{
Spatially explicit analysis of estuarine habitat for juvenile winter flounder: combining generalized additive models and geographic information systems
}

\author{
Allan W. Stoner* ${ }^{*}$ John P. Manderson, Jeffrey P. Pessutti \\ Behavioral Ecology Branch, Northeast Fisheries Science Center, National Marine Fisheries Service, 74 Magruder Road, \\ Highlands, New Jersey 07732, USA
}

\begin{abstract}
Quasisynoptic seasonal beam trawl surveys for age-0 winter flounder Pseudopleuronectes americanus were conducted in the Navesink River/Sandy Hook Bay estuarine system (NSHES), New Jersey, from 1996 to 1998, to develop spatially explicit models of habitat association. Relationships between environmental parameters and fish distribution were distinctly nonlinear and multivariate. Logistic generalized additive models (GAMs) revealed that the distribution of newly settled flounder $(<25 \mathrm{~mm}$ total length) in spring collections was associated with low temperature and high sediment organic content, placing them in deep, depositional environments. Fish 25 to $55 \mathrm{~mm}$ total length were associated with high sediment organics, shallow depth $(<3 \mathrm{~m})$, and salinity near 20 ppt. The largest age-0 fish ( 56 to $138 \mathrm{~mm}$ ) were associated with shallow depths $(<2 \mathrm{~m})$, temperature near $22^{\circ} \mathrm{C}$, and presence of macroalgae. Abundance of prey organisms contributed significantly to the GAM for fish 25 to $55 \mathrm{~mm}$ total length, but not for fish $>55 \mathrm{~mm}$. Independent test collections and environmental measurements made at 12 new sites in NSHES during 1999 showed that the GAMs had good predictive capability for juvenile flounder, and new GAMs developed for the test set demonstrated the robustness of the original models. Maps for the probability of capturing fish of particular sizes were produced by integrating GAMs with maps of environmental data in a geographic information system (GIS). These plots revealed 2 important centers of settlement in the system, probably related to hydrographic conditions, and the fact that nursery locations shift rapidly with fish size during the first year of life. It was also apparent that nursery habitats are dynamic-expanding, contracting, and shifting position with changes in key environmental variables.
\end{abstract}

KEY WORDS: Habitat · Nursery · Spatial analysis · Generalized additive model $\cdot$ Estuary $\cdot$ Flounder

\section{INTRODUCTION}

Increasing pressure from human development necessitates the identification and preservation of habitats critical for survival and sustainable utilization of estuarine and marine species. The urgent need for habitat-related fisheries management was recognized formally by the United States Congress in 1996 amend-

${ }^{*}$ Present address: Fisheries Behavioral Ecology Program, Alaska Fisheries Science Center, NOAA/NMFS, 2030 South Marine Science Drive, Newport, Oregon 97365, USA.

E-mail: al.stoner@noaa.gov ments to the Magnuson-Stevens Fishery Conservation and Management Act requiring that US government fishery agencies and councils protect and conserve the habitats of fishery resources. 'Essential Fish Habitat' (EFH) was defined as 'those waters and substrate necessary to fish for spawning, breeding, feeding, or growth to maturity'. Habitat provisions of the Magnuson-Stevens Act assume that there is a positive relationship between the quantity of essential fish habitat (e.g., total surface area) and fish abundance or productivity. Such a relationship is expected on the basis of MacCall's basin model (MacCall 1990, and see Petitgas 1998), but rarely tested because exact habitat re- 
quirements are often poorly known and because of the difficulties inherent in synoptic assessment of underwater habitats. Rijnsdorp et al. (1992) found a direct positive relationship between nursery habitat area and recruitment level of Solea solea in the North Sea, English Channel, Bristol Channel, and Irish Sea, and Gibson (1994) concluded that there is sufficient evidence that both quality and quantity of nursery grounds have significant effects on flatfish recruitment.

Flatfishes are among the best studied of marine fishery species because of their abundance and association with soft-bottom substrata, yet Gibson (1994) noted that the habitats of most flatfishes (500 to $600 \mathrm{spp}$.) are known only in the most general ways. This ordinarily includes information on general locations, depth distribution, and some knowledge of relationships with temperature and sediment characteristics. Basic qualitative descriptions of habitat association have been reported for numerous commercially significant species (Kuipers 1977, Powell \& Schwartz 1977, Becker 1988, Pihl \& van der Veer 1992, Rogers 1992, Jager et al. 1993, Able \& Kaiser 1994, Swain \& Morin 1997, Gibson et al. 1998), but there has been relatively little consideration of early juvenile stages, ontogenetic shifts in habitat, and the possible interactions among the numerous environmental factors that can influence flatfish distribution.

Winter flounder Pseudopleuronectes americanus is a commercially significant pleuronectid flatfish that occurs in estuarine and continental shelf waters in the northwest Atlantic from Labrador to Georgia (Bigelow \& Schroeder 1953). In the mid-Atlantic Bight, adult winter flounder move offshore during the summer when inshore water temperatures are high, then back into bays and estuaries during winter and early spring to spawn (Phelan 1992, Scarlett \& Allen 1992, Stoner et al. 1999). Demersal eggs and larvae are retained in these bays and estuaries (Crawford \& Carey 1985, Keller et al. 1999). The larvae settle in the spring at a length of 9 to $13 \mathrm{~mm}$ and reach 60 to $80 \mathrm{~mm}$ by the first winter (Able \& Fahay 1998). Because juveniles have been collected in a wide variety of habitats including sand, mud, vegetated and unvegetated substrata, Able \& Fahay (1998) concluded that young-of-the-year fish have no distinct habitat preference. Growth rates are known to vary considerably between different estuaries (Sogard \& Able 1992) and among different locations within estuaries (Sogard 1992), but growth (Phelan et al. 2000) was not predictable on the basis of habitat types, including seagrass beds, macroalgal beds, and unvegetated substrata.

Recent investigations have shown that new computerintensive statistical modelling methods are particularly robust in accommodating multiple nonparametric relationships between animals and environmental vari- ables. Using regression tree analysis, Norcross et al. (1997) modelled flatfish habitat in Alaska, and Rejwan et al. (1999) analyzed nesting site locations for smallmouth bass Micropterus dolomieui in a Canadian lake. Swartzman et al. (1992) described the use of generalized additive models (GAMs) in modelling flatfish habitat in the Bering Sea, and this method was applied subsequently in modelling habitat for walleye pollock Theragra chalcogramma in the Bering Sea (Swartzman et al. 1995) and for herring Clupea harengus in the North Sea (Maravelias \& Reid 1997, Maravelias 1999).

In this investigation we combine GAM with geographic information systems (GIS) to conduct a spatially explicit analysis of habitat utilization by age-0 winter flounder in the Navesink River/Sandy Hook Bay estuarine system (NSHES), New Jersey. The primary hypotheses were that there is significant sizerelated variation in the habitat associations of age- 0 fish, and that environmental parameters can be used to predict changes in fish distribution. We also hypothesized that the quantity of suitable habitat would vary over time because fish respond to multiple environmental variables, including some that are dynamic (e.g., salinity, food abundance) rather than static or fixed in position (e.g., sediment type, water depth). The analysis of habitat association was based upon $2 \mathrm{yr}$ of quasisynoptic seasonal surveys of physical factors, sediment characteristics, and biological elements of the habitat including prey. Independent test sets were collected during a third year to test the predictive capabilities of the models. The combination of statistical and graphical approaches allowed us to create maps showing the probability of capturing flounder and changes in potential habitat for particular size groups over time. Analysis of winter flounder nursery habitat requirements is particularly urgent in the northeastern US because estuaries there are already heavily industrialized and urbanized.

\section{MATERIALS AND METHODS}

Study site. The NSHES (Fig. 1) was chosen for this study because it is a known spawning ground (Stoner et al. 1999) and nursery (Phelan et al. 2000) for winter flounder. While the system is relatively small, it has features typical of the numerous riverine estuaries in the Mid-Atlantic Bight and Long Island Sound. The Navesink River is a flood-dominated estuary and has strong horizontal gradients in physical features because it has just 1 major freshwater source. Most of the river is shallow ( $<2 \mathrm{~m}$ at MLW [mean low water]) with a partially dredged channel (3 $\mathrm{m}$ deep) down its axis. The apex of Sandy Hook Bay is also shallow with numerous sand 


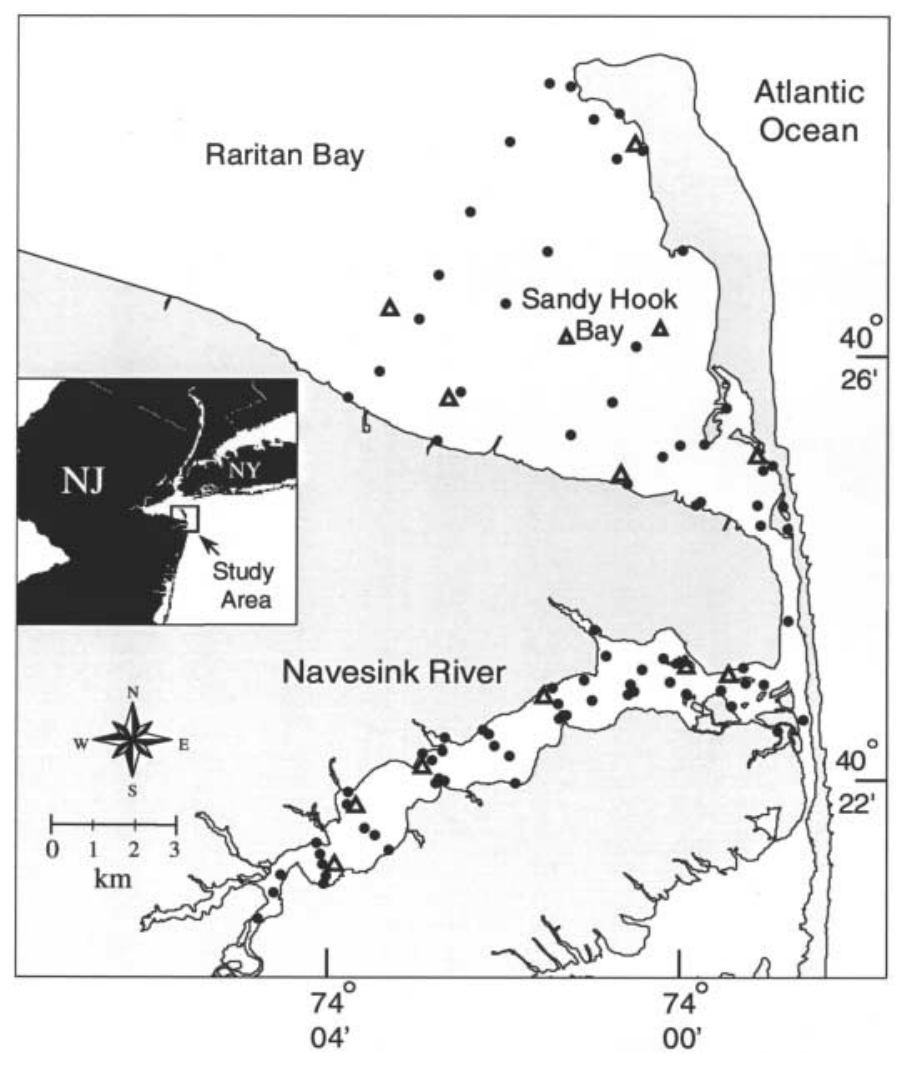

Fig. 1. Navesink River/Sandy Hook Bay estuarine system (NSHES) in the New York Bight apex, showing the 84 fixed stations (•) where data were collected during 1996 to 1998 for development of generalized additive models (GAM) for winter flounder habitat. $(\triangle) 12$ stations used in an independent test set for the GAMs in 1999

bars and a dredged channel (4 $\mathrm{m}$ deep). The deeper outer section of the bay ( $>6 \mathrm{~m}$ ) has fine mud sediments and high organic content (see 'Results'). The entire system has a semi-diurnal tide with a range of approximately $1.4 \mathrm{~m}$. Seasonal temperatures range from near $0^{\circ} \mathrm{C}$, with winter ice cover, to over $30^{\circ} \mathrm{C}$ in mid-summer. The bottom of the bay is primarily mud and sand. The river bottom is also mostly soft sediments with small patches of the seagrass Zostera marina in the eastern sections (not sampled), and beds of sea lettuce Ulva lactuca and the red algae Gracilaria sp., which are most extensive in late summer.

Field collections. Six seasonal collections of fishes and measurements of environmental characteristics were made over a 2 yr period (1996 to 1998) for this investigation. Juvenile winter flounder were collected at 84 fixed stations in NSHES (Fig. 1) at the end of July and end of October in 1996 and 1997, and at the end of May in 1997 and 1998. May collections were timed to provide data for newly settled flounder, while the summer and fall seasons yielded age-0 fish in a variety of sizes, particularly those 33 to $138 \mathrm{~mm}$ in total length (TL). Fish were collected with 2 replicate tows made with a $1 \mathrm{~m}$ wide beam trawl (3 mm mesh liner to collect the smallest flounder) (Kuipers 1975). Towing speed (60 $\mathrm{m} \mathrm{min}^{-1}$ ) was higher than that recommended for European plaice (30 to $35 \mathrm{~m} \mathrm{~min}^{-1}$ ) (Riley \& Corlett 1966) but similar to the tow speed used for Paralichthys spp. in North Carolina (Kuipers et al. 1992). Preliminary collections yielded higher catch rates with the higher tow speed. Tows in the river and bay were 30 and $60 \mathrm{~s}$ in duration, respectively. Longer tows would have been preferred, but abundance of amphipod tubes and loose macroalgae resulted in rapid blocking of the mesh. We placed emphasis on a large number of tows, high replication of habitat types, and comprehensive spatial coverage. Kuipers $(1973,1977)$ has shown that tidal height has an important effect on the movements of plaice on the shallow banks (Balgzand) of the Wadden Sea, and that the fish exhibit a relatively random distribution during high water. Unlike the Balgzand, only a narrow fringe of NSHES is exposed at low water, and depths in Sandy Hook Bay are typically $>6 \mathrm{~m}$; however, we sampled all of the shallowest stations near high water to reduce the potential artifact of tidal migrations (Kuipers 1973). Positions were determined at the beginning of each tow with differential global positioning systems (dGPS). All winter flounder were extracted from the samples, counted, and measured for total length, and abundance was standardized to numbers of individuals per $10 \mathrm{~m}^{2}$.

For this investigation, age-0 winter flounder were divided into 3 size classes: $<25,25$ to 55 , and $>55 \mathrm{~mm}$ TL. Divisions were made on the basis of cluster analysis of dietary information for flounders collected in NSHES (Stehlik \& Meise 2000). There is little other detailed information on the ecology of age-0 winter flounder, but we concluded that diets provide an indication of changing capabilities, prey preferences, and habitat associations. Fish $<25$ mm TL consume primarily calanoid and harpacticoid copepods and small spionid polychaetes. This size class yielded substantial numbers of individuals representing newly settled fish. Fish 25 to $5 \mathrm{~mm}$ TL consume calanoid copepods, spionids, and larger polychaetes. At $55 \mathrm{~mm}$ TL, the diets of winter flounder in NSHES shift from calanoid copepods and small polychaetes to larger crustaceans such as amphipods and mysids and siphons of the bivalve Mya arenaria. For this size group we included only those fish considered part of the age-0 cohort as revealed in length-frequency plots for each survey. The exact size ranges for each size group considered in this analysis are reported in Table 1. 
Table 1. Temperature, salinity, and number of winter flounder collected in Navesink River/Sandy Hook Bay estuarine system (NSHES) surveys from July 1996 to May 1998. Values for temperature and salinity are means (ranges). Letter codes show groups of surveys with similar average salinities in pairwise comparison tests. Temperatures were significantly different between all surveys. Values for winter flounder are numbers of individuals collected, frequency of occurrence in tows [\% of tows with flounder], and range of total length in mm (in parentheses). Each survey included 168 tows

\begin{tabular}{|c|c|c|c|c|c|c|}
\hline Year/Season & Dates & $\begin{array}{l}\text { Temp. } \\
\left({ }^{\circ} \mathrm{C}\right)\end{array}$ & $\begin{array}{c}\text { Salinity } \\
\text { (ppt) }\end{array}$ & $\begin{array}{c}\text { Age-0 } \\
<25 \mathrm{~mm}\end{array}$ & $\begin{array}{c}\text { Age-0 } \\
25-55 \mathrm{~mm}\end{array}$ & $\begin{array}{c}\text { Age-0 } \\
>55 \mathrm{~mm}\end{array}$ \\
\hline \multicolumn{7}{|l|}{1996} \\
\hline Summer & 22 Jul-8 Aug & $23.2(21.6-26.3)$ & $20.4^{\mathrm{b}}(9.2-24.0)$ & 0 & $56[13.4](33-54)$ & 99 [31.5] (55-117) \\
\hline Fall & 23 Oct -5 Nov & $13.1(9.0-16.3)$ & $19.9^{\mathrm{b}}(0.7-27.9)$ & 0 & $3[1.8](46-54)$ & $63[26.8](56-126)$ \\
\hline \multicolumn{7}{|l|}{1997} \\
\hline Spring & 20 May-6 Jun & $15.9(13.4-18.7)$ & $21.6^{\mathrm{b}}(0.0-31.0)$ & 104 [20.8] (12-24) & $155[28.0](25-51)$ & 0 \\
\hline Summer & $14-23 \mathrm{Jul}$ & $25.6(21.4-31.2)$ & $24.0^{\mathrm{c}}(11.0-35.0)$ & 0 & $18[8.3](42-54)$ & 49 [17.9] (55-96) \\
\hline Fall & $21-30$ Oct & $11.8(9.7-15.0)$ & $26.0^{\mathrm{C}}(13.5-28.8)$ & 0 & 0 & $16[7.1](74-138)$ \\
\hline \multicolumn{7}{|l|}{1998} \\
\hline Spring & 18 May-1 Jun & $18.2(13.6-21.5)$ & $17.0^{\mathrm{a}}(0.2-29.9)$ & 26 [6.5] (10-24) & 37 [12.5] (25-54) & 0 \\
\hline
\end{tabular}

During each visit to a station, bottom temperature and salinity were measured with electronic probes (Yellow Springs Instruments). We determined the wet weight $\left(\mathrm{g} \mathrm{m}^{-2}\right)$ of macroalgae, sponges and colonial bryozoans collected in each beam trawl.

Sediments and benthos were collected at each station in early July 1997. At most stations samples were collected with a weighted and frame-mounted Van Veen grab $\left(400 \mathrm{~cm}^{2}\right)$ deployed from a $8 \mathrm{~m}$ work boat. Samples were collected with a pole-mounted Ekman grab $\left(240 \mathrm{~cm}^{2}\right)$ where water depth permitted access only with a smaller boat. In all cases, penetration of the grab was 12 to $15 \mathrm{~cm}$, and 3 replicate samples were collected. A core sample (3 cm diam., $5 \mathrm{~cm}$ depth) was taken from each of the grabs for analysis of grain size and organic content. These subsamples were held on ice, then frozen until subsequent analysis. The remainder of each grab sample was sieved with a $0.5 \mathrm{~mm}$ screen and preserved with $10 \%$ formalin for identification and enumeration of benthic macrofauna. Macrofaunal abundance is high (30000 to 100000 ind. $\mathrm{m}^{-2}$ ) in NSHES during the summer, and coefficients of variation within stations averaged just $16 \%$ for the 3 samples; therefore, the size and number of grab samples provided a good indication of food distribution over the system.

In the laboratory, sediments were analyzed by standard sieve fractionation (Folk 1966), and productmoment statistics (McBride 1971) were calculated for mean grain size and sorting coefficients (both in units of $\Phi)$. Organic content was determined by incineration of dry sediment at $550^{\circ} \mathrm{C}(4 \mathrm{~h})$ in a muffle furnace.

Macrofauna were sorted from the sediments, identified to lowest possible taxon and counted. Densities were standardized to number of individuals per $\mathrm{m}^{2}$. In this study, we considered only those organisms that serve as prey for winter flounder. Toward this goal we included species within taxonomic groups (usually families) that comprised more than $5 \%$ of the prey by volume in dietary studies conducted concurrently with this study in NSHES (Stehlik \& Meise 2000). For flounder 25 to $55 \mathrm{~mm}$ TL this included spionid polychaetes (Marenzellaria viridis, Polydora cornuta, Prionospio steenstrupi, Scolelepis squamata, Spio armata, Spiophanes bombyx, and Streblospio benedicti) and ampeliscid amphipods (Ampelisca abdita, A. vadorum). For the larger fish (>55 mm TL) this included the taxa above plus newly recruited soft clam Mya arenaria and gammarid amphipods Gammarus mucronatus. Prey for fish $<25 \mathrm{~mm}$ were not considered because a large proportion of the diet was planktonic.

Analytical approach. We used binomial GAMs, which are nonparametric generalizations of logistic regression (Hastie \& Tibshirani 1990), to examine relationships between winter flounder of different size classes and environmental variables (Table 2). Although GAMs can be applied to data with any type of distribution, including abundance data, we chose a more conservative approach using binomial data (i.e., presence-absence). Given the sampling inefficiencies and limitations of towed gear discussed earlier, we concluded that constructing models to predict absolute abundance would be unrealistic. The binomial models provided estimates for the probability of capturing winter flounder that are especially useful in habitat evaluation. In an earlier study, Norcross et al. (1999) found that logistic regression provided simple habitat models that were accurate and broadly applicable for flatfish species in Alaska and required relatively few environmental variables.

Binomial GAMs iteratively fit scatterplot smoothers to relationships between the response frequencies 
Table 2. List of environmental variables considered in generalized additive models (GAMs) for winter flounder. Natural log transformations were applied as noted. TL: total length

\begin{tabular}{|c|c|}
\hline Parameter & Method of measurement or collection \\
\hline Water depth & Sounding lead or fathometer reading, corrected for tidal height $(\mathrm{m})$ \\
\hline Bottom temperature & Electronic probe $\left({ }^{\circ} \mathrm{C}\right)$ \\
\hline Bottom salinity & Refractometer or electronic probe (ppt) \\
\hline Sediment characteristics & Grab samples \\
\hline Grain size & Standard sieve fractionation and product-moment statistics $(\Phi)$ \\
\hline Sorting coefficient & Standard sieve fractionation and product-moment statistics $(\Phi)$ \\
\hline Organic content & Loss in dry weight by ignition (\% of dry weight) \\
\hline Shell content & Percent of weight in fraction $>0.5 \mathrm{~mm}$ \\
\hline Biogenic features & Beam trawl collections \\
\hline Macroalgal biomass & Wet weight $\left[\ln \left(\mathrm{g} \mathrm{m}^{-2}+1\right)\right]$ \\
\hline Sponge biomass & Wet weight $\left[\ln \left(\mathrm{g} \mathrm{m}^{-2}+1\right)\right]$ \\
\hline Bryozoan biomass & Wet weight $\left[\ln \left(\mathrm{g} \mathrm{m}^{-2}+1\right)\right]$ \\
\hline Prey abundance & Grab samples \\
\hline for fish $25-55 \mathrm{~mm} \mathrm{TL}$ & Ampeliscids \& spionids $\left[\ln \left(\right.\right.$ no. $\left.\left.\mathrm{m}^{-2}\right)\right]$ \\
\hline for fish $>55 \mathrm{~mm} \mathrm{TL}$ & Ampeliscids, spionids, gammarids, Mya arenaria $\left[\ln \left(\right.\right.$ no. $\left.\left.\mathrm{m}^{-2}\right)\right]$ \\
\hline
\end{tabular}

(logits) of the dependent variable and independent environmental variables. Because GAMs assume only that the response is a function of the sum of unspecified smoothed nonparametric functions, they allow for data-defined assessments of the shapes of species responses to the independent variables. Interactions among the variables can be considered and confidence bands can be calculated for each function (Efron \& Tibshirani 1991).

Our GAMs were constructed with S-Plus software (Math-Soft Inc., Seattle, Washington), using a cubic spline smooth and default degrees of freedom $(=4)$ (Hastie 1991, Venables \& Ripley 1997). The models were constructed manually in a forward stepwise manner. Terms were added to the model such that each step resulted in the largest significant reduction in residual deviance when compared to the previous model using an approximate chi-square test (Hastie 1991). Thus the initial term is not tested against another and has no $\mathrm{p}$ value. First order interaction between terms already included in models was also tested similarly for contribution to the overall model. The additive effects were plotted with confidence intervals $( \pm 2 \mathrm{SE})$ to graphically evaluate the relative effects of each environmental variable on the probability of capturing winter flounder. The pattern in the distribution of residuals is related to the binomial response, with observations above and below the curve corresponding to presences and absences, respectively. Deviance is analogous to the variance, and the null deviance is roughly analogous to total variance. Therefore, null deviance minus residual deviance is the deviance explained by the model.

Station coordinates were transformed because of the complex configuration of the study area and existence of significant land barriers. Transformation was achieved in a piecewise manner by splitting the study area at the narrow reach between the Navesink River and Sandy Hook Bay to form 2 sets of stations (river and bay). Then the universal transverse mercator projection (UTM) coordinates of the stations in the 2 sets were rotated independently to align the central axis on the study area with a new $x$ axis using the equations:

$$
\begin{aligned}
& x^{\prime}=x \cos \theta-y \sin \theta \\
& y^{\prime}=x \sin \theta+y \cos \theta
\end{aligned}
$$

where $\theta$ is the angle of rotation, and $x, y$ and $x^{\prime}, y^{\prime}$ are the old and new coordinates. The new $y$ coordinates in the 2 sets were centered around their means and the sampling space was reassembled. Thus, the new $x$ axis represented the approximate distance in meters along the axis of the study area from the westernmost station in the Navesink River to the north and central area of Sandy Hook Bay. The new $y$ coordinates represented the cross-sectional distances of the stations from the new $x$ axis.

The transformed $x$ and $y$ station coordinates were used in omnidirectional correlellograms with Moran's I statistic (Legendre \& Legendre 1998) to test for spatial autocorrelations and in the GAMs to examine the amount of residual coarse-scale spatial variation in winter flounder distributions which was not related to habitat parameters included in the models.

All winter flounder $<25 \mathrm{~mm}$ TL were collected in spring surveys; therefore, the GAM for this classification was developed from 336 beam trawl collections from the 2 May surveys. Winter flounder in the 25 to $55 \mathrm{~mm}$ size class were collected in spring and summer surveys, yielding 672 collections for modelling. Age-0 flounders $>55 \mathrm{~mm}$ were collected in the summer and 
fall seasons, also yielding 672 collections for GAM analysis. We used all of the dates when fish of particular size classes were present to develop habitat models as general as possible. Although pooling of dates probably increased residual deviance in the models, we wanted to develop models that were not date-specific and could be applied broadly in NSHES and tested in other estuaries.

Continuous probability surfaces of winter flounder presence were generated from GAMs using ArcView GIS software (ESRI, Redlands, California). The 84 survey stations were georeferenced and placed over a regional base map. Each station contained data for environmental variables considered in the analysis of flounder nurseries. Point values were then converted into a continuous grid covering the study area. Variables were gridded (cells $=250 \mathrm{~m}$ ) for each season separately, using inverse distance weighted averaging. The variable grid-cell values were then exported from ArcView and used in the GAMs to generate predicted probabilities of flounder occurrence. The predicted values were returned to ArcView for plotting.

Test sets. Distribution-based habitat models have rarely been tested with independent data sets (Beutel et al. 1999). To test the predictive capabilities of the GAMs, 3 collections were made during summer 1999 at 12 new locations representing diverse habitats throughout NSHES (Fig. 1). Three standard beam trawls and 4 replicate sediment samples were collected at each station during each sampling period (May 24, June 7, June 23). Temperature, salinity, and depth measurements were also made as required for the
GAMs. Sediment organics and macroalgal biomass were analyzed as described earlier.

Probabilities of capturing winter flounder in the 3 size classes were calculated using the size-specific GAMs and environmental data collected during the new surveys. We assumed that areas with high probability of capture should yield highest actual capture rates (capture per unit effort, CPUE). We used simple rank correlation analysis (Spearman) to measure the concordance between GAM predictions and mean flounder catch for each of the 36 collections. We also developed independent GAMs for the test sets using all of the new environmental data for comparison with the original models. While the new GAMs cannot have the precision of the original models because of the lower number of collections, similarities between the two would provide evidence for the importance of particular environmental variables.

\section{RESULTS}

\section{Environmental variables}

There were many significant correlations among the environmental variables measured in NSHES because of the large number of points included in the calculations; however, few of the correlation coefficients were high (Table 3 ). There was a high positive correlation between sediment phi and organic content ( $r=0.71$ ), and a weak negative correlation between salinity and both phi $(\mathrm{r}=-0.39)$ and organic content $(\mathrm{r}=-0.36)$. All

Table 3. Pearson correlation matrix for environmental variables in the NSHES. $x$ is the distance downstream from the westernmost station in the Navesink River. $y$ is the across-river or across-bay distance from the central axis of the system. Phi (mean grain size in units of $\Phi$ ), sorting (sorting coefficient), organic, shell, and detritus are all characteristics of the sediments described in the text. Algae is the biomass of all macroalgal species collected in beam trawls. Sponge is the biomass of sponges and colonial bryozoans collected in beam trawls. Significance of correlation coefficient: ${ }^{*}<0.05,{ }^{* *}<0.01,{ }^{* * *}<0.001$

\begin{tabular}{|c|c|c|c|c|c|c|c|c|c|c|c|c|}
\hline & $x$ & $y$ & Depth & Temp. & Salinity & Phi & Sorting & Organic & Shell & Detritus & Algae & Sponge \\
\hline$x$ & - & & & & & & & & & & & \\
\hline$y$ & -0.04 & - & & & & & & & & & & \\
\hline Depth & $0.51^{* * *}$ & $-0.28^{* * *}$ & - & & & & & & & & & \\
\hline Temp. & -0.05 & -0.02 & -0.02 & - & & & & & & & & \\
\hline Salinity & $0.61^{* * *}$ & 0.06 & $0.27^{* * *}$ & $-0.16^{* * *}$ & - & & & & & & & \\
\hline Phi & $-0.54^{* * *}$ & $-0.12^{*}$ & -0.05 & 0.05 & $-0.39^{* * *}$ & - & & & & & & \\
\hline Sorting & 0.08 & -0.02 & -0.01 & -0.01 & 0.04 & $-0.25^{* * *}$ & - & & & & & \\
\hline Organic & $-0.59^{* * *}$ & 0.02 & -0.08 & 0.03 & $-0.36^{* * *}$ & $0.71^{* * *}$ & $-0.13^{* *}$ & - & & & & \\
\hline Shell & 0.04 & 0.03 & 0.11 & 0.00 & 0.01 & 0.01 & $0.15^{* * *}$ & * 0.04 & - & & & \\
\hline Detritus & -0.03 & 0.02 & 0.02 & 0.00 & 0.00 & $0.15^{* * *}$ & $0.12^{*}$ & $0.15^{* * *}$ & $0.14^{* *}$ & - & & \\
\hline Algae & -0.24 & 0.02 & $-0.21^{* * *}$ & $0.11^{*}$ & $-0.12^{* *}$ & $0.16^{* * *}$ & 0.04 & $0.15^{* * *}$ & -0.08 & 0.02 & - & \\
\hline Sponge & -0.16 & 0.02 & -0.03 & $-0.12^{*}$ & -0.04 & $0.19^{* * *}$ & -0.06 & $0.19^{* * *}$ & 0.01 & 0.00 & 0.10 & - \\
\hline
\end{tabular}



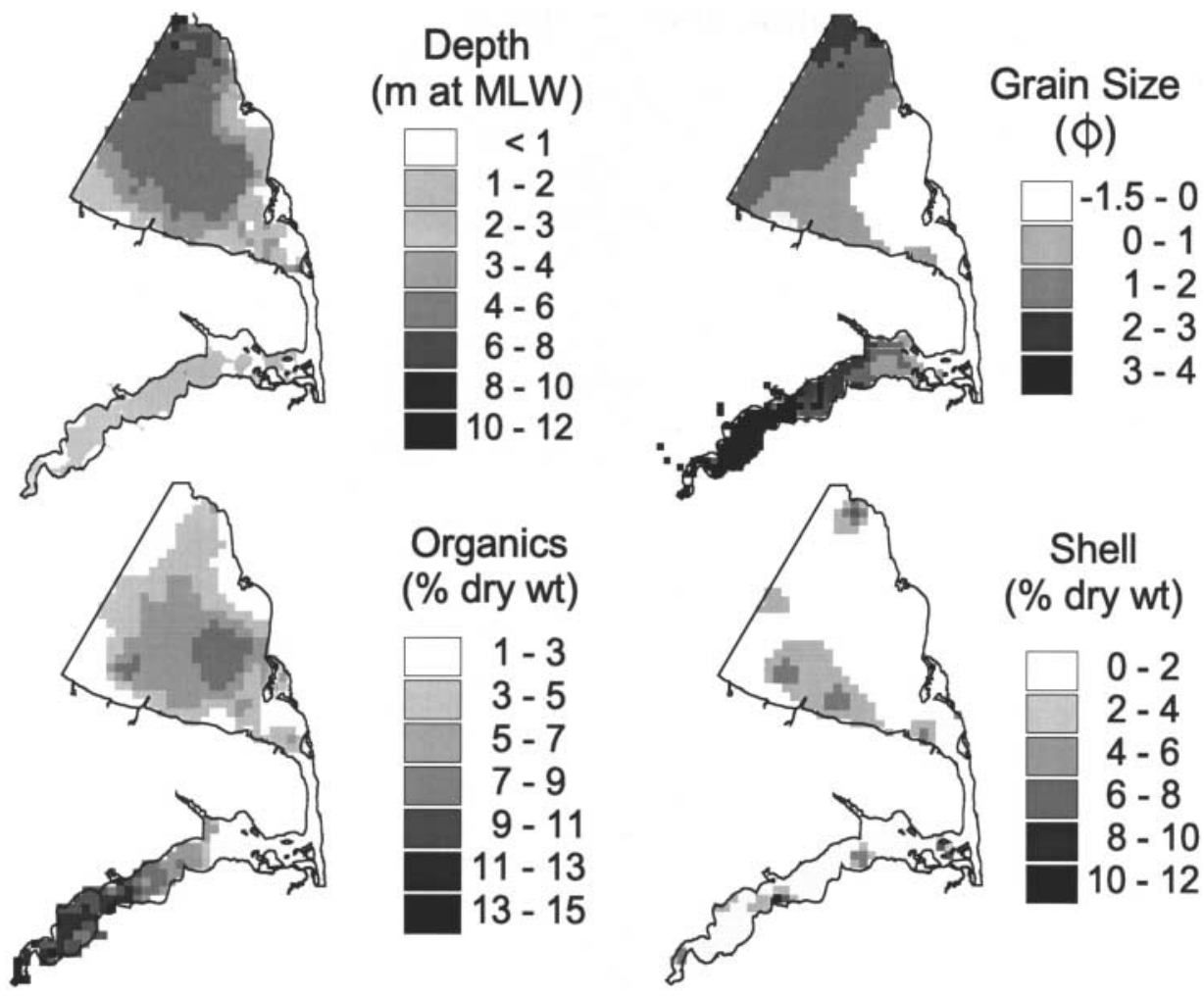

Fig. 2. Distribution of depth, sediment grain size, sediment organic content and sediment shell content in the NSHES. MLW: mean low water

other correlations were small (-0.25 to 0.27). Downstream gradients were evident in correlations with the geographic dimension $x$ (Table 3). Salinity and depth both increased downstream as would be expected, and sediment grain size and organic content decreased downstream. Macroalgal biomass also decreased downstream, but the relationship was weak $(\mathrm{r}=-0.24)$. As expected, depth decreased significantly with distance from the central axis of the system $(r=-0.28)$. This was the only environmental variable with a meaningful correlation with the $y$ dimension (Table 3).

Spatial patterns are apparent in maps for environmental variables (Fig. 2) assumed to be important to bottom-dwelling fish. Depth was greatest in the middle and outer part of Sandy Hook Bay. Finest sediments (large $\Phi$ ) occurred in the upper reaches of the Navesink River and along the northwest boundary of Sandy Hook Bay. Sediment organic content increased with increasing phi (Table 3), particularly in the river (Fig. 2). In the bay, however, organic content was highest near the center. Patches of sediment with high shell content occurred in both the river and bay, primarily in nearshore and shoal areas. Other variables, such as temperature, salinity, and macroalgal biomass, were highly variable with time and not mapped.

The most abundant prey items for young winter flounder in NSHES were ampeliscid amphipods and spionid polychaetes. The distributions were relatively similar (Fig. 3) with highest densities in the middle section of the Navesink River. There was a secondary maximum for ampeliscids along the south shore of the bay and for spionids in the upper reach of the river. After natural log transformation, prey organisms for winter flounder 25 to $55 \mathrm{~mm}$ were positively correlated with sediment phi $(\mathrm{r}=0.369, \mathrm{p}=0.001)$ and organic content $(r=0.416, p<0.001)$. Similar significant but weak correlations occurred for the prey of fish $>55 \mathrm{~mm}$ (phi, $\mathrm{r}=0.371, \mathrm{p}=0.001$; organics, $\mathrm{r}=0.393, \mathrm{p}<0.001$ ).

\section{Winter flounder populations}

Length-frequency plots (Fig. 4) for winter flounder collected in NSHES were relatively similar in the 3 seasonal pairs of collections, with increasing size of the age-0 cohort from spring to summer to fall. Median lengths of winter flounder in the spring 1997 and 1998 were identical at $27 \mathrm{~mm}$, with ranges of 11 to 55 and 10 to $60 \mathrm{~mm}$, respectively. In the summer, medians for age-0 fish were 62 and $65 \mathrm{~mm}$, and in the fall total lengths increased to 93 and $102 \mathrm{~mm}$ for 1996 and 1997 , respectively.

Strong positive or negative spatial autocorrelation (Moran's $I>0.25$ ) was not evident in the distribution of age-0 winter flounder except during the 1997 spring 




Fig. 3. Distribution of the primary prey items for juvenile winter flounder, ampeliscid amphipods and spionid polychaetes, in the NSHES in July 1997
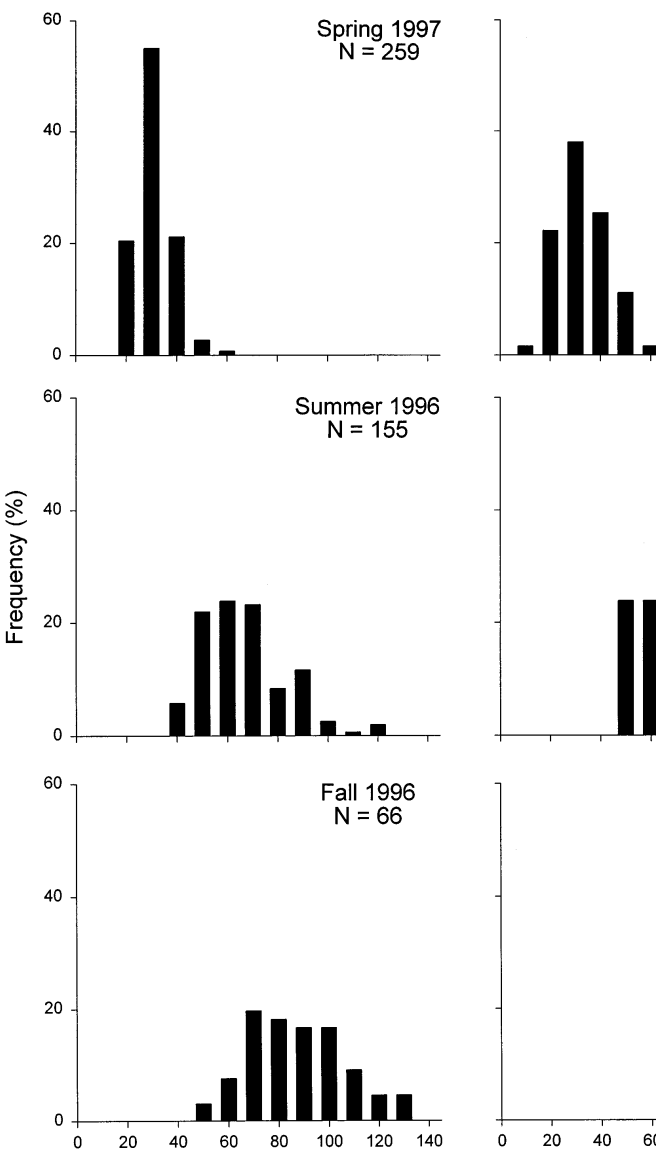
Spring
$N=63$


Total length $(\mathrm{mm})$

Fig. 4. Pseudopleuronectes americanus. Size-frequency distribution of age- 0 winter flounder collected in the NSHES during seasonal surveys in 1996 to 1998 survey. Recruitment was particularly heavy in spring 1997, and abundances of flounders $<25 \mathrm{~mm}$ and 25 to $55 \mathrm{~mm}$ TL were positively autocorrelated $(I>0.25)$ at lag distances $<1000 \mathrm{~m}$. The general lack of autocorrelation indicates that the fish were not typically aggregated on the large spatial scale sampled, and thus the stations could be considered independent for subsequent spatial analysis.

\section{Habitat models}

Newly settled flounder

Bottom water temperature, sediment organics, and salinity were the only environmental variables that resulted in significant reductions in deviance in the GAM for winter flounder $<25 \mathrm{~mm}$ TL (Table 4). Plots of model fit for the individual variables (Fig. 5) show that highest probabilities of collecting small winter flounder occur at temperatures $<16^{\circ} \mathrm{C}$, on sediments with relatively high organic content ( $>6 \%$ of dry weight), and in a salinity range of $\sim 13$ to 23 ppt. However, given the very broad confidence band for salinity, particularly at low salinity values, the influence is not clear.

There was a significant reduction in deviance (220.7 to 199.6, $\mathrm{p}=0.045$ ) when geographic variables ( $x$ and $y$ dimensions in the NSHES, and the interaction term) were added to the model. Residual deviance decreased $8 \%$ from the null.

When cell-based environmental data (i.e., temperature, organics, and salinity) for spring 1997 and spring 1998 were combined with the GAM to calculate and 
Table 4. Pseudopleuronectes americanus. Results of GAM for age-0 fish $<25 \mathrm{~mm}$ TL. Null deviance and residual deviance are shown for the overall model, along with marginal reductions in residual deviance (approximate chi-square test) associated with adding each term to the model. Interaction terms were not significant $(\mathrm{p}<0.05)$

\begin{tabular}{|lccc|}
\hline Null deviance (df) & $268.3(335)$ & & \\
Residual deviance (df) & $220.7(323)$ & & \\
Factor & Deviance & Reduction in deviance & $\mathrm{p}$ \\
\hline Temperature & 245.6 & 22.7 & \\
Organics & 230.1 & 15.5 & 0.003 \\
Salinity & 220.7 & 9.4 & 0.046 \\
\hline
\end{tabular}

plot the probability of capturing winter flounder $<25 \mathrm{~mm}, 2$ areas with high probabilities of capturing fish were observed in both years (Fig. 6). However, there were large annual differences in the surface area of high probability zones. The total area with a probability $>0.3$ was $79.6 \%$ less in 1998 than in 1997. Low probability of capture was associated with high temperatures throughout the system in 1998 (Table 1, Fig. 5).

\section{Juveniles 25 to $55 \mathrm{~mm}$}

Habitats of winter flounder 25 to $55 \mathrm{~mm}$ TL were best described with a GAM including several variables as well as interactions between sediment organics, temperature and salinity (Table 5). There was a strong positive effect associated with high organic content in the sediments ( $>6 \%$ of dry weight) (Fig. 7). Also, depth $<5 \mathrm{~m}$ and salinity in the range of 15 to $24 \mathrm{ppt}$ had positive effects on flounder occurrence. The effect of temperature appeared to be relatively minor (Fig. 7); however, seasonal and interannual effects probably caused the temperature $\times$ organics interaction. When temperature was high, in summer collections, flounders were concentrated in areas with low sediment organic content (i.e., values $<3$ to $4 \%$ of dry wt). The association

Table 5. Pseudopleuronectes americanus. Results of GAM for age-0 fish 25 to $55 \mathrm{~mm}$ TL. Null deviance and residual deviance are shown for the overall model, along with marginal reductions in residual deviance (approximate chi-square test) associated with adding each term to the model

\begin{tabular}{|lccc|}
\hline $\begin{array}{l}\text { Null deviance (df) } \\
\text { Residual deviance (df) }\end{array}$ & $\begin{array}{c}506.8(648) \\
\text { Factor }\end{array}$ & & \\
& Deviance & Reduction in deviance & $\mathrm{p}$ \\
\hline Organics & 601.5 & 23.0 & \\
Temperature & 579.1 & 22.4 & $<0.001$ \\
Depth & 558.4 & 20.8 & $<0.001$ \\
Salinity & 542.1 & 16.2 & 0.002 \\
Organics $\times$ Temperature & 516.4 & 25.7 & $<0.0001$ \\
Organics $\times$ Salinity & 506.8 & 9.6 & 0.042 \\
\hline
\end{tabular}

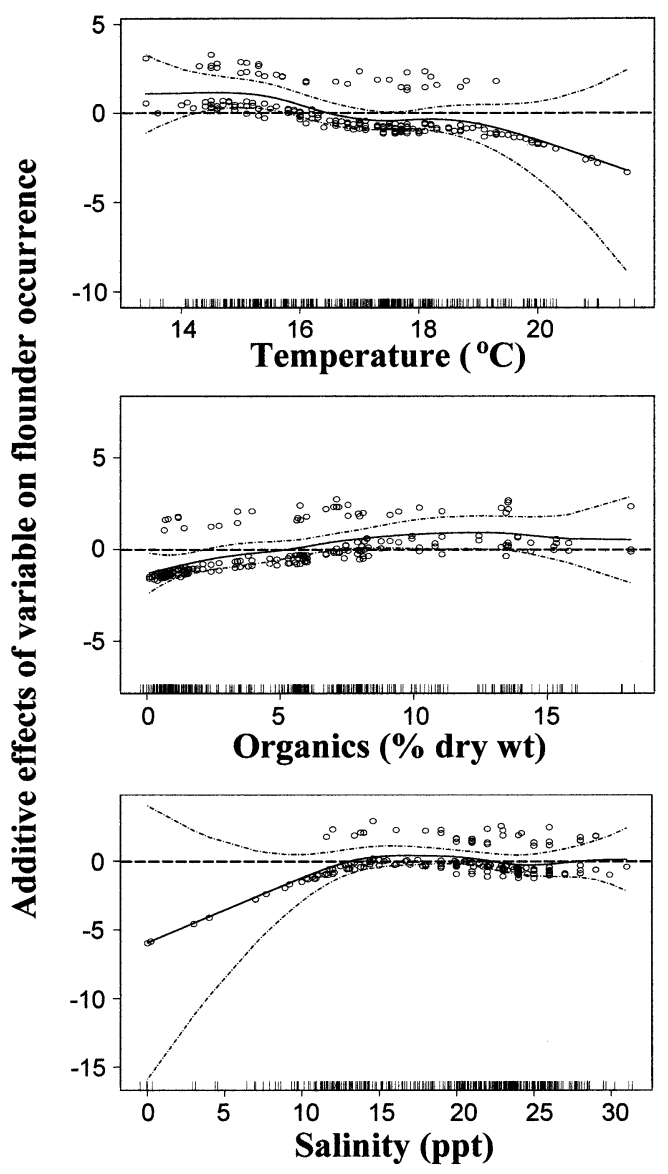

Fig. 5. Pseudopleuronectes americanus. GAM results for winter flounder $<25 \mathrm{~mm}$ TL. Plots show the additive effect of each variable on the presence/absence of fish and the partial residuals. Dotted lines represent 2 SE ranges around the main effects, and vertical dashes at the bottom of the plots show the distribution of points entering into the model

with sediment organics also varied with salinity. When salinity was high, fish of this intermediate size class were associated with low organics, but fish were found with a wide range of organic concentrations when salinity was low. In summary, when temperature was high, fish were associated with high salinity and low sediment organics. Because salinity increased and organic content decreased with distance from the river head, habitat for fish 25 to $55 \mathrm{~mm}$ TL moved out of the river during high temperature periods.

Adding the geographic terms resulted in a significant but relatively small (3.5\%) reduction of residual deviance in the overall model (506.8 to 485.1, p = 0.034).

GAM predictions for 25 to $55 \mathrm{~mm}$ winter flounder using cell-based environmental data for summer sampling periods (Fig. 8) 


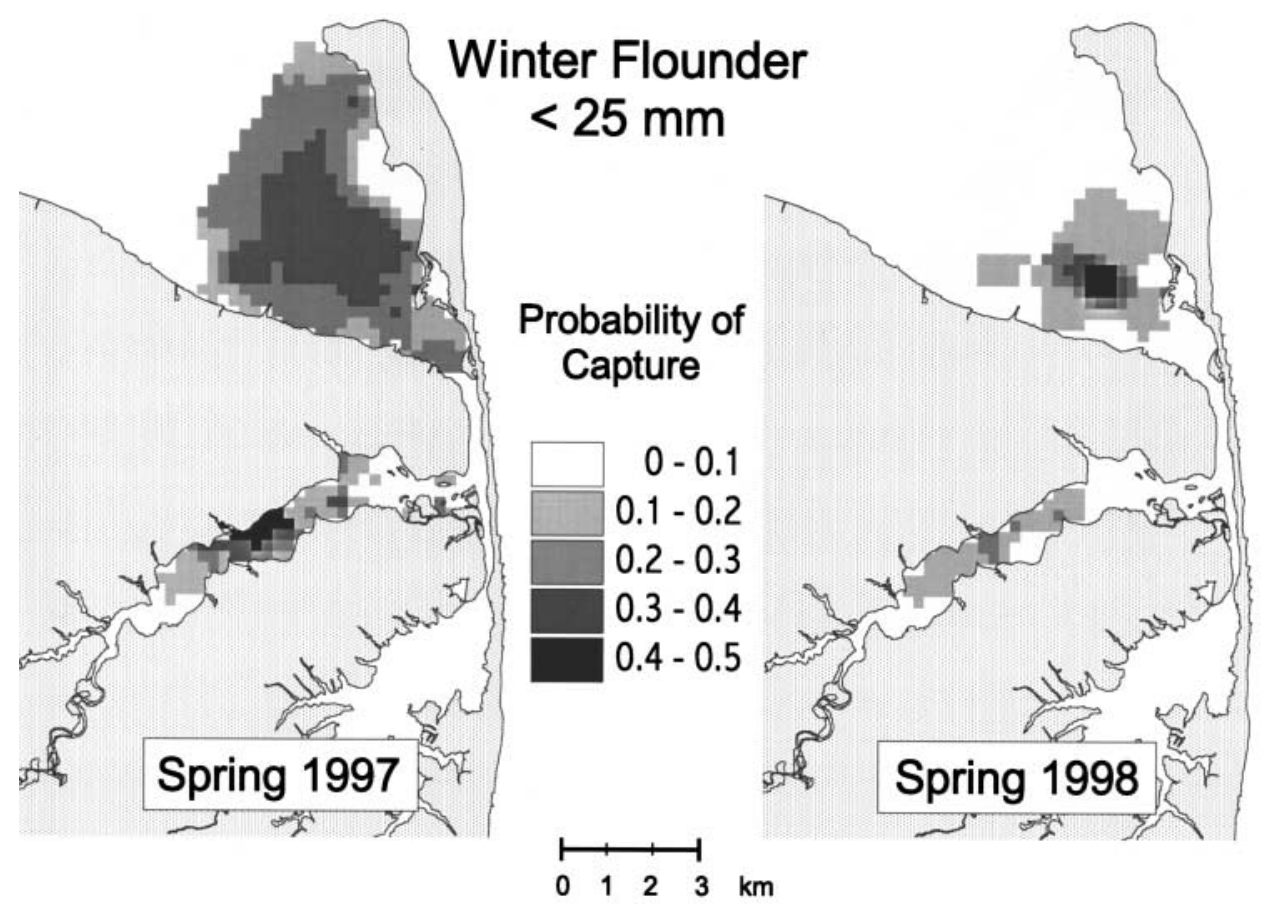

Fig. 6. Pseudopleuronectes americanus. Probability of capturing winter flounder $<25 \mathrm{~mm}$ TL in the NSHES calculated with the GAM for the size class and environmental variables (water temperature, sediment organic content, and salinity) observed in spring collections during 1997 and 1998

revealed that the highest probability of capturing fish occurred throughout most of the Navesink River and along the shores of Sandy Hook Bay in summer 1996. In summer 1997, probabilities of capture were <0.2 throughout NSHES, except for 11 cells in the lower reach of the Navesink. Low probabilities of capture were associated with a combination of high temperature, low salinity, and high sediment organics ob- served in the river during the 1997 summer survey. Thus, based upon the GAM for 25 to $55 \mathrm{~mm}$ fish, the best habitat for winter flounder occurred in the outer Navesink River and in Sandy Hook Bay, where coolest bottom temperatures were associated with intermediate depths and low sediment organics. In 1996, $4.1 \%$ of the study area had a probability of capturing 25 to $55 \mathrm{~mm}$ flounder $>0.3$; in 1997, the value was zero.
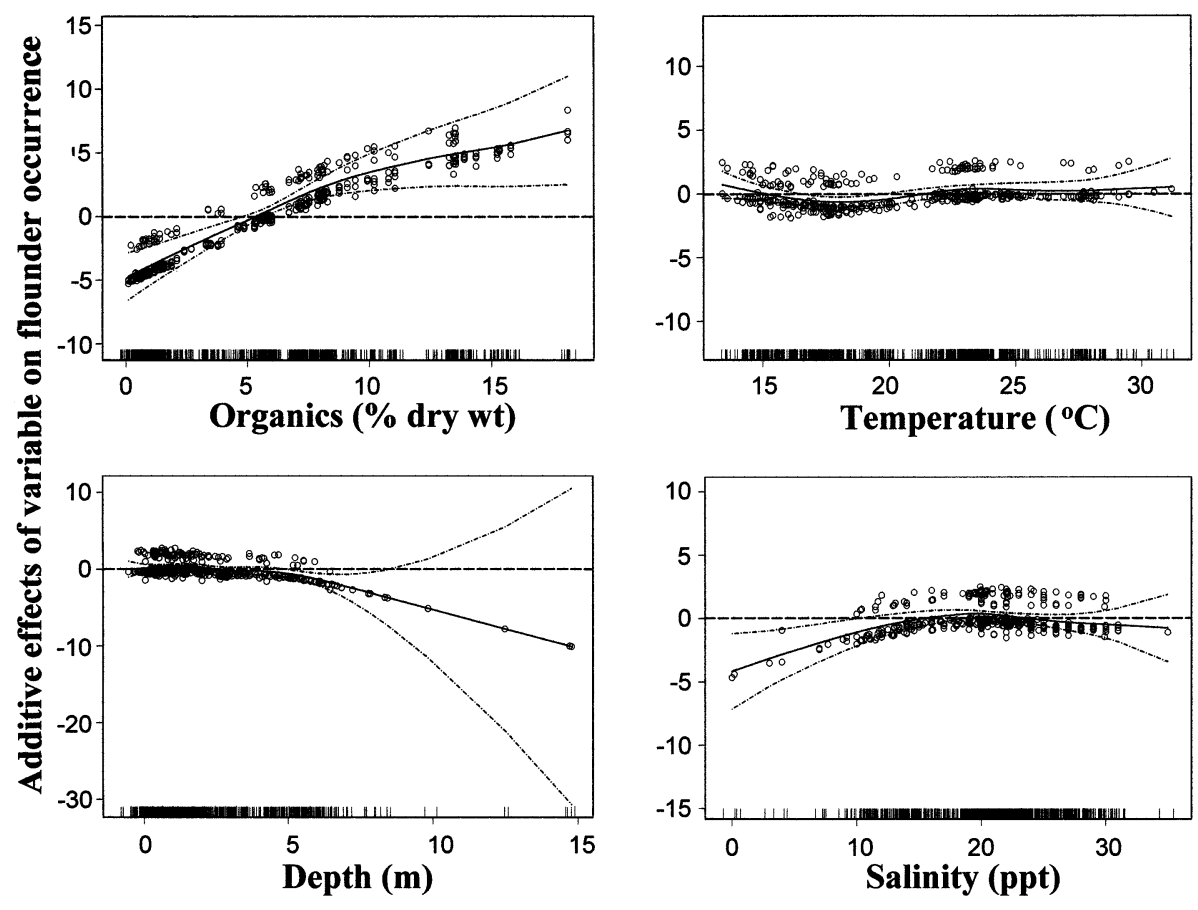

Fig. 7. Pseudopleuronectes americanus. GAM results for winter flounder 25 to $55 \mathrm{~mm}$ TL. Plots show the additive effect of each variable on the presence/absence of fish and the partial residuals. Dotted lines represent 2 SE ranges around the main effects, and vertical dashes at the bottom of the plots show the distribution of points entering into the model 
Table 6. Pseudopleuronectes americanus. Results of GAMs for age-0 fish 25 to $55 \mathrm{~mm}$ TL comparing models with and without potential prey as an environmental variable. The models were constructed with fish data collected only in spring and summer 1997, in conjunction with benthic prey collections. Null deviance and residual deviance are shown for the overall model, along with marginal reductions in residual deviance (approximate chi-square test) associated with adding each term to the model

\begin{tabular}{lccr} 
Without prey & & & \\
Null deviance (df) & $268.3(335)$ & & \\
Residual deviance (df) & $220.7(323)$ & & \\
Factor & Deviance & Reduction in deviance & $\mathrm{p}$ \\
\hline Temperature & 291.3 & 18.6 & \\
Organics & 272.7 & 18.6 & $<0.001$ \\
Salinity & 263.3 & 9.4 & 0.047 \\
Temperature $\times$ Organics & 236.9 & 26.4 & $<0.0001$ \\
& & & \\
With prey & & & \\
Null deviance (df) & $268.3(335)$ & & \\
Residual deviance (df) & $220.7(323)$ & & \\
Factor & Deviance & Reduction in deviance & \\
\hline Temperature & 294.8 & 23.5 & \\
Prey & 275.4 & 19.4 & 0.034 \\
Organics & 262.1 & 13.3 & 0.040 \\
Salinity & 252.0 & 25.6 & $<0.025$ \\
Temperature $\times$ Organics & 226.4 & & \\
\hline
\end{tabular}

spring and summer trawl surveys. Temperature, sediment organics, salinity, and the interaction between temperature and organics were included as significant variables in models with and without the prey variable (Table 6). This is similar to the overall (2 yr) analysis for 25 to $55 \mathrm{~mm}$ fish (Table 5), although the overall model also included water depth. When prey abundance was considered, it was the second most important term in the model with an effect nearly as large as temperature (Table 6). The plot for prey effects shows that 25 to $55 \mathrm{~mm}$ fish were least abundant in areas with low prey densities and most abundant in areas with prey in a range of 8000 to 10000 ind. $\mathrm{m}^{-2}$ (Fig. 9). However, inclusion of the prey variable produced only about a $4 \%$ improvement in the overall model.

\section{Age- 0 juveniles $>55 \mathrm{~mm}$}

As found with the smaller fish, winter flounder >55 mm TL, captured in summer and fall surveys, were associated with patterns of temperature, salinity, and depth, but

The effects of adding abundance of potential prey as an environmental variable in the GAM for distribution of 25 to $55 \mathrm{~mm}$ winter flounder was tested using the benthic survey data from July 1997 (Fig. 3) and fish data collected immediately before and after, in the algal biomass had a greater effect than sediment characteristics (Table 7). The highest abundance of fish was associated with depths $<2 \mathrm{~m}$, bottom water temperatures 16 to $27^{\circ} \mathrm{C}$, salinity $<23 \mathrm{ppt}$, and algal biomass $>3 \mathrm{~g} \mathrm{~m}^{-2}$ (Fig. 10). The pattern of interaction

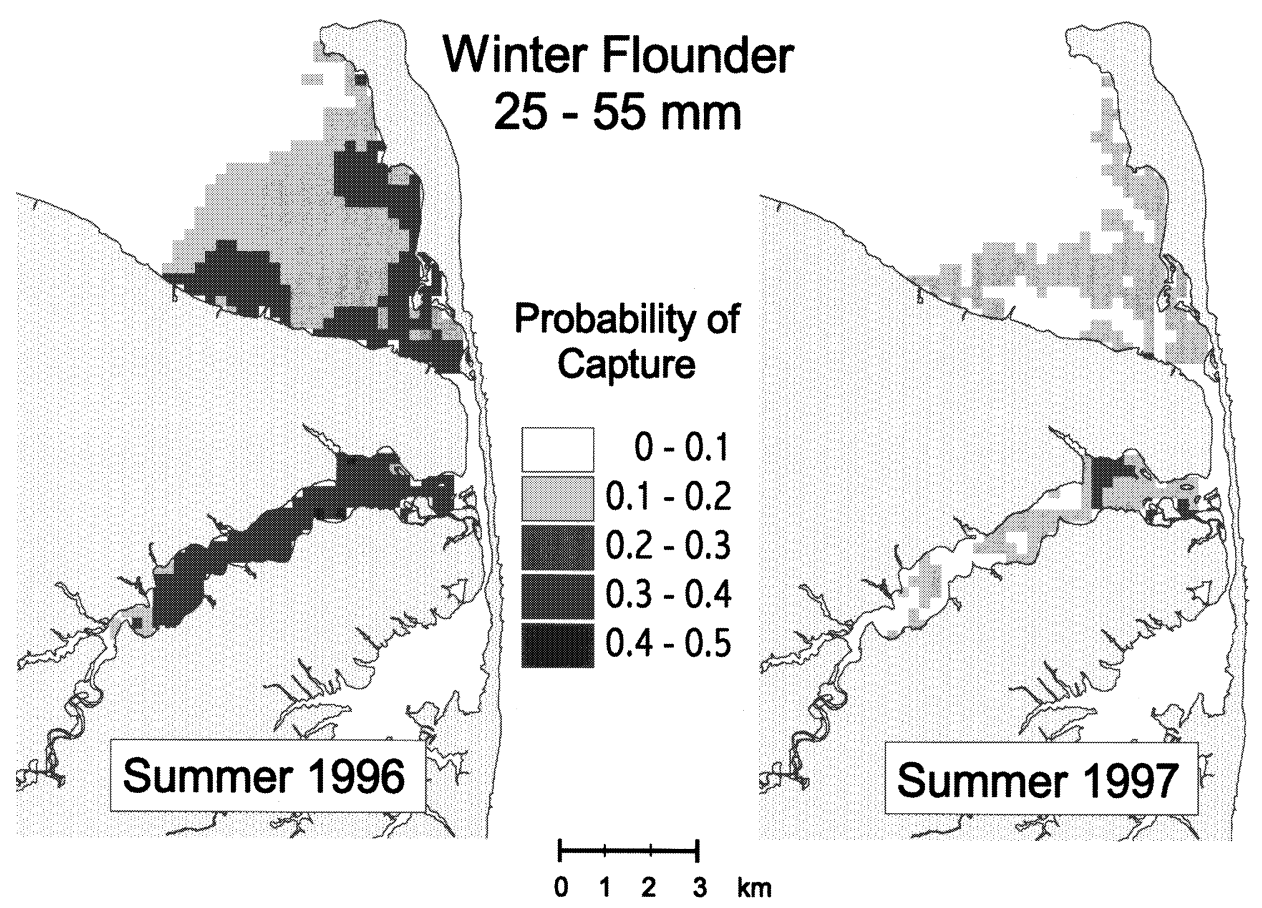

Fig. 8. Pseudopleuronectes americanus. Probability of capturing winter flounder 25 to $55 \mathrm{~mm}$ TL in the NSHES calculated with the GAM for the size class and environmental variables (sediment organic content, water temperature, depth, and salinity) observed in the summer season 1996 and 1997 
Table 7. Pseudopleuronectes americanus. Results of GAM for age-0 $>55 \mathrm{~mm}$ TL. Null deviance and residual deviance are shown for the overall model, along with marginal reductions in residual deviance (approximate chi-square test) associated with adding each term to the model

\begin{tabular}{|lccr|}
\hline $\begin{array}{l}\text { Null deviance (df) } \\
\text { Residual deviance (df) }\end{array}$ & $\begin{array}{c}\text { 487.8 (671) } \\
\text { Factor }\end{array}$ & & \\
& Deviance & Reduction in deviance & $\mathrm{p}$ \\
\hline Depth & 655.9 & 31.9 & \\
Temperature & 629.3 & 26.6 & $<0.001$ \\
Salinity & 609.6 & 19.7 & $<0.001$ \\
Algae & 593.1 & 16.6 & 0.002 \\
Temperature $\times$ Algae & 490.2 & 102.8 & $<0.001$ \\
Temperature $\times$ Salinity & 481.7 & 8.5 & 0.018 \\
& & & \\
\hline
\end{tabular}

was relatively similar in 1997 , but probabilities of capture were low (mostly <0.2) throughout because of low temperatures in the system during the fall 1997 (Table 1, Fig. 11), and less broad distribution of macroalgae. The area with probability values $>0.3$ for capturing age-0 fish > $55 \mathrm{~mm}$ decreased $70 \%$ between 1996 and 1997.

Abundance of potential prey was added as an environmental variable in the GAM for distribution of juvenile winter flounder $>55 \mathrm{~mm}$ using the data for summer 1997. The best model reduced null deviance from 157.7 $(\mathrm{df}=167)$ to residual deviance of 122.9 (df = 159), and included only depth and salinity. As in the overall model for this size class,

between temperature and algal biomass was not clear; however, high catch probabilities were associated with the combination of high temperature and high salinity. Significant reduction in the residual deviance occurred with addition of geographic variables to the overall model (481.7 to $460.3, \mathrm{p}=0.043)$, but model improvement was only $3.1 \%$.

Plots of habitat quality from the GAM for winter flounder $>55 \mathrm{~mm}$ and cell-based environmental data for fall sampling periods showed relatively high probabilities of capturing large juveniles in both 1996 and 1997 (Fig. 11) compared with smaller fish. In 1996, the highest probabilities occurred along the west side of Sandy Hook peninsula and around the periphery of the Navesink River because of the association with shallow water and macroalgae. The geographic pattern highest catch frequencies were associated with depths of 1 to $3 \mathrm{~m}$. Unlike the overall model (based upon $2 \mathrm{yr}$ ), fish in the summer season were associated primarily with high salinity values (>26 ppt) and cooler water in the bay, and prey concentration did not contribute significantly to reduction in deviance.

\section{Test sets}

Winter flounder were present in $53 \%$ of the 108 trawl samples collected in the model-testing phase of this study during 1999. The ranges of environmental variables observed during the test period were: 16 to $25^{\circ} \mathrm{C}$ temperature, 18 to 26 ppt salinity, 0.5 to $17 \%$ of dry weight for sediment organic content, 0.5 to $6 \mathrm{~m}$ depth, and 0 to $14 \mathrm{~g}$ wet wt $\mathrm{m}^{-2}$ of macroalgal biomass. CPUE of newly settled winter flounder (<25 mm TL) was significantly correlated ( $\rho=0.293, p=0.041$ ) with the calculated probability of capturing fish in that size class (i.e., GAM for fish <25 mm, using temperature, sediment organics, and salinity). The correlation was also significant for age-0 fish >55 (i.e., GAM using depth, temperature, salinity, and macroalgal biomass) ( $\rho=0.384$, $\mathrm{p}=0.012$ ). Abundance of fish $25-55 \mathrm{~mm}$ was not well predicted using the GAM for this size class $(\rho=0.103, p=0.271)$; instead there was a significant correlation with probability calculated from the model for fish $>55 \mathrm{~mm}$ $(\rho=0.424, p=0.006)$. The primary difference between the 2 models is the inclusion of algal biomass in the GAM for fish >55 (Fig. 10), instead of sediment organic content (for fish 25 to $55 \mathrm{~mm}$ ) (Fig. 7), while the relationships with depth and salinity were similar.

When independent GAMs were developed for the test set collections water temperature
Fig. 9. Pseudopleuronectes americanus. GAM results for winter flounder 25 to $55 \mathrm{~mm}$ TL. Plot shows the effect of prey abundance on the presence/absence of fish and the partial residuals. Dotted lines represent $2 \mathrm{SE}$ ranges around the main effect, and vertical dashes at the bottom of the plot show the distribution of points entering into the model 
was the most important variable entering the model for fish $<25 \mathrm{~mm}$ (Table 8 ). The second and only other variable in the test set model was sediment phi. This is different from the original GAM, where sediment organic content was the second term; however, organics and phi are highly correlated (Table 3). The fact that salinity did not enter the new model is not surprising because the range during the test set surveys was only $8 \mathrm{ppt}$, in contrast with the range of $31 \mathrm{ppt}$ observed during spring collections for the original GAM. The model derived from test set data for fish 25 to $55 \mathrm{~mm}$ (Table 8) was most similar to the original model for fish > $55 \mathrm{~mm}$ (Table 7), incorporating salinity, depth, and macroalgal biomass, but without temperature and interaction terms. Inspection of the GAM plots for the new test set model revealed that the relationships between fish and the independent variables were similar to those in the original model (Fig. 10).
Table 8. Pseudopleuronectes americanus. Results of GAMs for fish in 2 size classes collected in 1999 test sets. Null deviance and residual deviance are shown for the overall model, along with marginal reductions in residual deviance (approximate chi-square test) associated with adding each term to the model

\begin{tabular}{lccc} 
Flounder <25 $\mathbf{~ m m ~ T L}$ & & & \\
Null deviance (df) & $87.0(107)$ & & \\
Residual deviance (df) & $64.7(99)$ & & \\
Factor & Deviance & Reduction in deviance & $\mathrm{p}$ \\
\hline Temperature & 75.4 & 11.6 & \\
Grain size & 64.7 & 10.7 & 0.027 \\
& & & \\
Flounder 25 to 55 mm TL & & & \\
Null deviance (df) & $147.3(107)$ & & $\mathrm{p}$ \\
Residual deviance (df) & $59.5(95)$ & & \\
Factor & Deviance & Reduction in deviance & \\
\hline Salinity & 102.2 & 45.1 & 0.001 \\
Depth & 84.7 & 17.5 & $<0.0001$ \\
Algae & 59.5 & 25.2 & \\
\end{tabular}

\section{DISCUSSION}

\section{Centers of recruitment for winter flounder}

The most intensive investigations of winter flounder habitat have resulted in the conclusion that the species is a habitat generalist with broad tolerances for salinity and temperature (Howell \& Molnar 1995, Able \& Fahay 1998, Phelan 2000). Juvenile winter flounder can, in fact, tolerate wide ranges of physical conditions like many estuarine animals; however, the conclusion of habitat generality may stem from rapid shifts in habitat association with size during the first weeks of demersal life and the complex combination of variables that constitute optimal habitat.



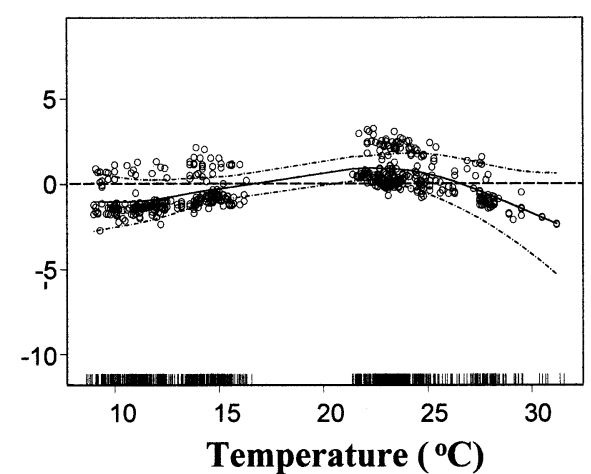

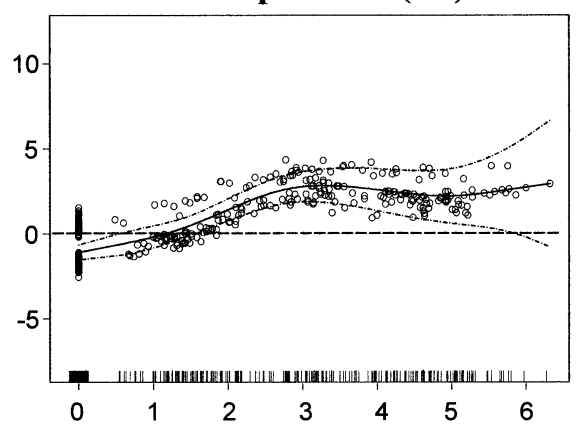

Algae $\left[\ln \left(g\right.\right.$ wet $\left.\left.w t \cdot \mathbf{m}^{-2}\right)\right]$
Fig. 10. Pseudopleuronectes americanus. GAM results for winter flounder $>55 \mathrm{~mm}$ TL. Plots show the additive effect of each variable on the presence/absence of fish and the partial residuals. Dotted lines represent $2 \mathrm{SE}$ ranges around the main effects, and vertical dashes at the bottom of the plots show the distribution of points entering into the model 


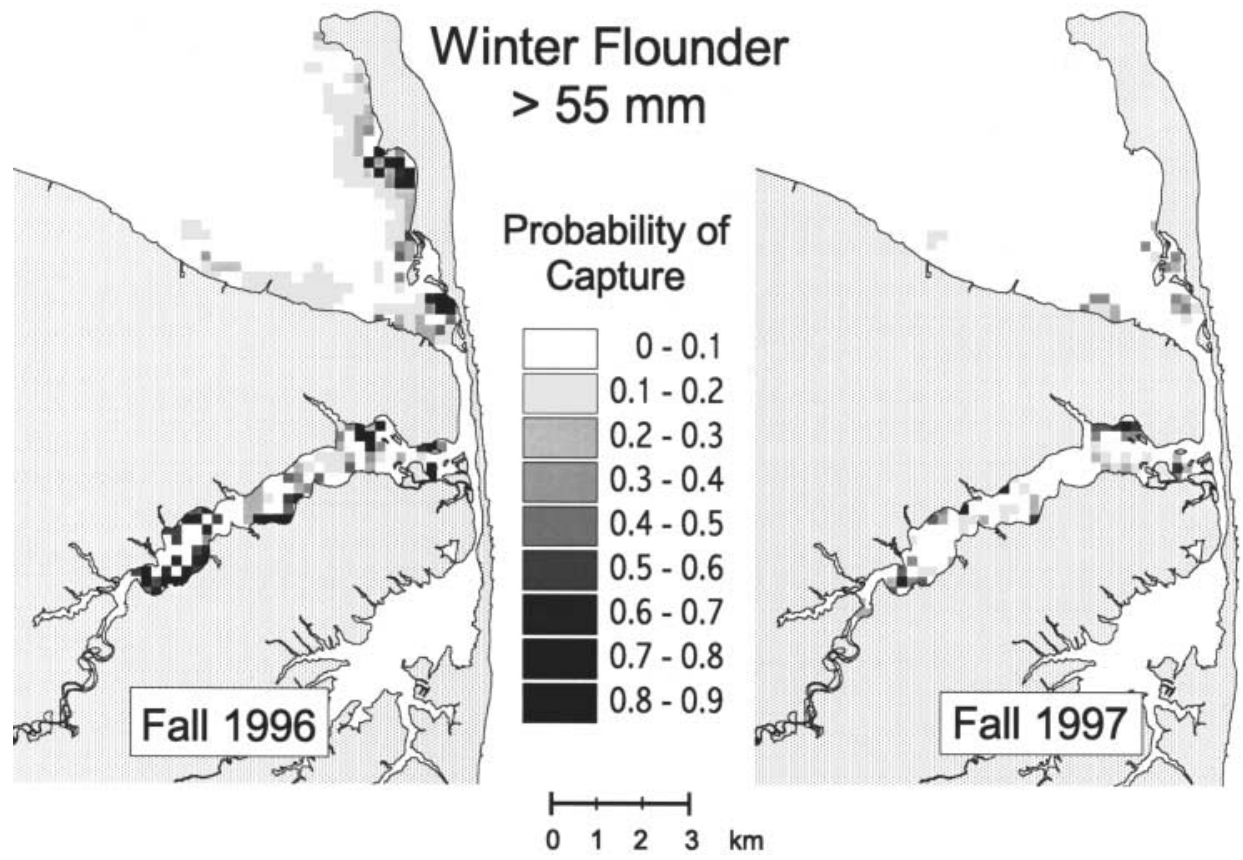

Fig. 11. Pseudopleuronectes americanus. Probability of capturing age- 0 winter flounder $>55 \mathrm{~mm}$ total length in the NSHES calculated with the GAM for the size class and environmental variables (depth, water temperature, salinity, and macroalgal biomass) observed in the fall season 1996 and 1997
Our beam trawl survey revealed a geographic context in winter flounder distribution within NSHES, particularly during the early post-settlement period. There were 2 apparent centers of flounder recruitment, one near the center of Sandy Hook Bay and the other in the middle reach of the Navesink River. Two different mechanisms could affect this distributional pattern: (1) Physical conditions could concentrate winter flounder larvae at both locations. The Navesink River is flood-dominated, with upstream transport of particulate materials and rapid attenuation of tidal currents in the middle reach (Chant \& Stoner 2001) where the smallest winter flounder were most abundant. Also, there is a quasi-stationary cyclonic gyre over the deeper, low-energy center of Sandy Hook Bay (Hires \& Mellor 1988), where the smallest juveniles were found in abundance. Despite these physical features, winter flounder larvae were widespread throughout the NSHES in surveys conducted in 1990 (Scarlett 1991) and 1999 (M. Fahay unpubl. data), and passive concentration of larvae does not appear to be the most likely mechanism for the observed early recruitment pattern. (2) A more plausible explanation for these centers of recruitment is differential settlement. Both locations accumulate fine sediment, organic materials, and benthic macrofauna because of the physical conditions described above, and laboratory trials have shown that small winter flounder have a strong affinity for these habitat features (Phelan et al. 2001). Consequently, it is likely that the fish settle preferentially in the 2 specific locations, resulting in their apparent concentration and significant spatial autocorrelation when small juveniles were particularly abundant in spring 1997. In accordance with our observations of winter flounder, Paralichthys spp. appear to settle in relatively specific locations in estuaries of North Carolina and then disperse with age (Walsh et al. 1999).

\section{Environmental variables and ontogenetic shifts in habitat}

Temperature was the most important environmental variable in the GAM for winter flounder $<25 \mathrm{~mm}$ TL. The cool water association $\left(<16^{\circ} \mathrm{C}\right)$ could be related to a habitat preference or result from settlement in deep depositional habitats of NSHES where surface heating in late spring did not occur as rapidly as in shallower parts of the system. For flounders 25 to $55 \mathrm{~mm}$ TL, the relationship with temperature appeared to be confounded with season (and perhaps other variables) because the fish were associated with cool water $\left(<16^{\circ} \mathrm{C}\right)$ in spring collections and water warmer than $\sim 22^{\circ} \mathrm{C}$ in the summer survey. It is possible that 25 to $55 \mathrm{~mm}$ fish were still concentrated near the settlement sites in spring collections and dispersed more widely in the summer, yielding the apparent differences in temperature response. In laboratory experiments, somewhat larger winter flounder (120 to $130 \mathrm{~mm} \mathrm{TL}$ ) selected temperatures 8 to $27^{\circ} \mathrm{C}$ with a modal temperature preferendum of $\sim 19^{\circ} \mathrm{C}$ (Casterlin \& Reynolds 1982). This corresponds with our findings of a strong positive association of flounder $>55 \mathrm{~mm}$ with temperatures near $22^{\circ} \mathrm{C}$ and a probability of capture declining 
rapidly at temperatures $>25^{\circ} \mathrm{C}$. Temperature associations have been reported for other flatfishes (Swartzman et al. 1992, Norcross et al. 1997, 1999), but preferenda may change with ontogeny.

Salinity was included in GAMs for all 3 size classes considered, but only as the third or fourth variable, and negative effects of salinity appeared to occur primarily at salinities <10 ppt. Although Armstrong (1995) found maximum growth of winter flounder juveniles in laboratory tests with salinities of 22 to $32 \mathrm{ppt}$, he reported collection of juveniles in meso- and polyhaline regions of Great Bay Estuary, New Hampshire. Salinity ranges have been part of the microhabitat identification for various flatfishes in estuaries of North Carolina (Powell \& Schwartz 1977, Walsh et al. 1999), Louisiana (Allen \& Baltz 1997) and the Chesapeake Bay (Derrick \& Kennedy 1997).

Habitat descriptions for flatfishes often include sediment characteristics because these fishes are closely associated with the bottom (Scott 1982, Rogers 1992, Swartzman et al. 1992, Norcross et al. 1997) and exhibit known preferenda (Moles \& Norcross 1995, Neuman \& Able 1998). Sediment type can effect burial behavior (Gibson \& Robb 1992) and the distribution of both prey and predators (Pihl \& van der Veer 1992, van der Veer \& Witte 1993, Manderson et al. 1999, 2000). Sediment associations were particularly important in the GAMs for the 2 smallest winter flounder size classes in NSHES. Probabilities of collecting fish $<55 \mathrm{~mm}$ increased rapidly with sediment organic content, and this was identified as the most significant environmental parameter for distribution of fish $<25 \mathrm{~mm}$. Because there was a direct correlation between organic content and phi, our modelling results are consistent with the laboratory finding that winter flounder 20 to $40 \mathrm{~mm}$ have strong preference for sediments in muddy and fine sand categories (Phelan et al. 2001). No sediment characteristics entered into the GAM for flounder $>55 \mathrm{~mm}$, and this is consistent with the laboratory finding that fish $>60 \mathrm{~mm}$ showed only a weak preference for sediment type.

Whereas newly settled fish were associated with organic-rich depositional environments in deeper basins or where current velocities were low, fish $>55 \mathrm{~mm}$ were strongly associated with depths of just 1 to $2 \mathrm{~m}$. Similarly, Armstrong (1997) found highest numbers of winter flounder juveniles at shallow sites (1.5 and $2.1 \mathrm{~m}$ ) in the fall, when age-0 fish were largest. Depth is one of the variables considered most often in analyses related to flatfish distribution (Baltus \& van der Veer 1995, Gibson 1997, Norcross et al. 1999), and ontogenetic patterns have been reported for a few species (Allen \& Baltz 1997, Abookire \& Norcross 1998, Walsh et al. 1999), but investigators have rarely considered the relatively rapid shifts in depth distribution within the age-0 cohort (e.g., Toole et al. 1997).
Macroalgal biomass entered into the GAM for fish $>55 \mathrm{~mm}$ and proved important in the distribution of 25 to $55 \mathrm{~mm}$ fish in test sets. Probability of capturing large juveniles increased logarithmically with algal biomass, but only up to $\sim 20 \mathrm{~g}$ wet weight $\mathrm{m}^{-2}$. Laboratory experiments have shown that small amounts of algal cover provide important shelter from predation (Manderson et al. 2000), but young winter flounder avoid high concentrations of Ulva lactuca and other algae in laboratory setting (Timmons 1995). High biomass levels could impede locomotion or access to sedimentdwelling foods, and create low oxygen conditions at night, as has been observed in the Navesink River during the summer (Phelan et al. 2000). In intensive beam trawl surveys conducted in 3 estuarine systems of New Jersey and Connecticut, Phelan (2000) found that there were no differences in the abundance of winter flounder in adjacent sites with and without macroalgae, but size (8 to $100+\mathrm{mm}$ TL) was not considered. The importance of physical structure in the habitat of juvenile winter flounder was also suggested by Howell \& Molnar (1995), who found that winter flounder were most abundant on sediments containing shell or woody debris and least abundant on muds and sands without these larger components.

The potential role of prey abundance in the distribution of flatfishes has been suggested repeatedly (McIntyre \& Eleftheriou 1968, Miller et al. 1991, Sogard 1992, Jager et al. 1993, Gibson 1994, 1997). Some laboratory experiments have been conducted on habitat choices related to prey (Mattila \& Bonsdorff 1998, Wennhage \& Gibson 1998), but relatively few quantitative field assessments of the relationship between prey and fish distribution have been made because of the difficulty in quantifying the abundance of appropriate prey items. In one study, Pihl \& van der Veer (1992) found no correlation between plaice density and biomass of macrofauna, but relationships to growth are inconsistent (van der Veer \& Witte 1993, Berghahn et al. 1995).

When data on prey were available for the modelling process in this study, prey abundance was a significant contributor in the models for juveniles 25 to $55 \mathrm{~mm}$, but not for those $>55 \mathrm{~mm}$. Recent experiments in our laboratory have shown that juvenile winter flounder choose habitats with prey over those without prey (Phelan et al. 2001), but associations in the field are confounded by numerous potential interactions between sediment qualities and prey abundance. First, the primary prey of juvenile winter flounder, spionid polychaetes and ampeliscid amphipods, are very abundant throughout NSHES in the summer, and prey may be limiting in only a few locations. Second, prey organisms and flounders were both associated with fine sediments and high organic content. Therefore, without controlled 
experiments, it is difficult to determine whether sediment qualities or prey concentration are most important in the distribution of winter flounder.

Significant contribution of the geographic variables ( $x$ and $y$ dimensions) to the GAMs reveals that we did not measure every environmental variable relevant to winter flounder distribution. Variables that could be considered in the future are current velocity, water turbidity, and dissolved oxygen concentration. Walsh et al. (1999) concluded that turbidity was an important factor affecting the distribution and ontogenetic shifts in habitat utilization by several flatfishes in North Carolina. Also, certain shrimps, fishes, and birds are known predators on flatfishes and may have a significant role in affecting distributional patterns and recruitment (Bailey 1994, Gibson 1994, Witting \& Able 1995, van der Veer et al. 1997, Leopold et al. 1998, Manderson et al. 1999). We believe that progress related to distributional ecology will profit from a community-based approach in the future, where predator-prey dynamics both above and below the subject species are considered to be part of the habitat.

Ontogenetic shifts in habitat are well recognized in many marine fishes, yet distributional patterns are generally reported only by year class, particularly for commercially significant species. This may be inappropriate because fishes in size-structured populations often express rapid ontogenetic variation in feeding ecology (Stoner 1980, Livingston 1982) and habitat requirements (Livingston 1984, 1988) during the first year of post-settlement life. While ontogenetic habitat shifts probably occur in continua, we observed that age-0 winter flounder 8 to $138 \mathrm{~mm}$ TL need to be considered in at least 3 different functional groups. Allen \& Baltz (1997) reported a similar need for analysis of small size groups in age-0 flatfishes from Barataria Bay, Louisiana. It is now clear that some of the difficulties in characterizing habitats for flatfishes have been exacerbated by pooling animals over year classes or size intervals that are too large.

\section{Spatially explicit habitat models_limitations and significance}

We acknowledge the following limitations of our models: First, data mining techniques can only find patterns in data if patterns actually exist (Brodley et al. 1999), and models can give an impression of more definitive, quantifiable relationships than actually exist. There was, in fact, a substantial amount of unexplained deviance in our habitat models for winter flounder. However, unlike many previous studies, we made independent collections to test our models. The original models proved to have substantial predictive power at locations previously unsampled in NSHES, and when independent GAMs were generated for the test sets (with many fewer data points), most of the same variables were identified as being important. Second, the distribution-based models are correlational, they do not necessarily represent habitat suitability, and there is a clear need to understand the underlying mechanisms of the habitat associations identified. Beutel et al. (1999) pointed out some of the limitations and assumptions of distribution-based models of habitat quality, and suggested that more direct measures, such as growth or survivorship, may be more appropriate. We agree. Despite the limitations, the models indicate some of the parameters and ranges of parameters that might be related to habitat suitability and provide a useful first step toward the design of hypothesis-driven studies to define and measure the effects of specific environmental variables on fitness components. In addition, spatially explicit models, such as those developed in this study, permit several important research applications that are not otherwise possible. These include (1) predictions of species distribution and movement patterns, including those related to dynamic characteristics of the habitat (e.g., temperature, salinity, etc.), (2) identification of habitats needed for conservation of the species, (3) an opportunity to test relationships between habitat and fish abundance or productivity (few such data are available), and (4) predictions of the effects of habitat disturbance or destruction.

The combination of GAMs and GIS allowed us to visualize temporal variation in the location and dimensions of potential habitat for juvenile winter flounder in NSHES. Areas with high probability of capturing specific size classes expanded, contracted, and moved over time. Centers of abundance for winter flounder $<25 \mathrm{~mm}$ occurred in approximately the same locations in spring 1997 and 1998, but the severe reduction of appropriate habitat in 1998 could have had a significant effect on total production of the 1998 year class. Other differences in surface area of appropriate habitat were evident between summer 1996 and 1997 (25 to $55 \mathrm{~mm}$ fish), and probabilities of capturing flounders $>55 \mathrm{~mm}$ were very low in Sandy Hook Bay in the fall 1997, compared with fall 1996. This dynamic ecoscape probably has a profound influence not only on the distribution, but on the abundance and productivity of winter flounder from year to year. Long-term surveys coupled with good habitat information will be critical in determining the effects of habitat area on cohort productivity and how the relationships may be linked to abiotic forces ranging from local rainfall events to global warming.

Traditionally, flatfish distribution has been described by year class and in terms of relatively static features 
such as depth, sediment grain size, and large-scale temperature patterns. It is now clear that habitat requirements shift rapidly with age within the first year, and that dynamic features such as local temperature patterns, sediment organics, and macrophyte cover can play a critical role in inshore and estuarine habitats (Allen \& Baltz 1997, this study). It is also clear that, because of the dynamic nature of certain habitat features, nursery grounds can expand, contract, and shift in location over time. For the long-term conservation of species it is essential that we learn to identify and protect critical habitats and determine whether or not habitat quantity affects total recruitment and productivity.

Acknowledgements. We wish to thank A. Bejda, J. Buckel, F. Morello, B. Phelan, J. Rosendale, P. Shaheen, L. Stehlik, and the numerous volunteers and interns from Rutgers University and Brookdale Community College who assisted in the intensive field and laboratory work associated with this project. T. Finneran helped with various computing problems. J. Buckel, C. Meise, L. O'Brien, B. Phelan, L. Stehlik and anonymous reviewers helped to improve the manuscript.

\section{LITERATURE CITED}

Able KW, Fahay MP (1998) The first year in the life of estuarine fishes in the Middle Atlantic Bight. Rutgers Univ Press, New Brunswick, NJ

Able KW, Kaiser SC (1994) Synthesis of summer flounder habitat parameters. NOAA Coastal Ocean Program Decision Analysis Series No. 1. NOAA Coastal Ocean Office, Silver Spring, MD

Abookire AA, Norcross BL (1998) Depth and substrate as determinants of distribution of juvenile flathead sole (Hippoglossoides elassodon) and rock sole (Pleuronectes bilineatus), in Kachemak Bay, Alaska. Neth J Sea Res 39: 113-123

Allen RL, Baltz DM (1997) Distribution and microhabitat use by flatfishes in a Louisiana estuary. Environ Biol Fish 50: 85-103

Armstrong MP (1995) A comparative study of the ecology of smooth flounder, Pleuronectes putnami, and winter flounder, Pleuronectes americanus, from Great Bay estuary, New Hampshire. PhD dissertation, University of New Hampshire, Durham

Armstrong MP (1997) Seasonal and ontogenetic changes in distribution and abundance of smooth flounder, Pleuronectes putnami, and winter flounder, Pleuronectes americanus, along estuarine depth and salinity gradients. Fish Bull 95:414-430

Bailey KM (1994) Predation on juvenile flatfish and recruitment variability. Neth J Sea Res 32:175-189

Baltus CAM, van der Veer HW (1995) Nursery areas of solenette Buglossidium luteum (Risso, 1810) and scaldfish Arnoglossus laterna (Walbaum 1792) in the southern North Sea. Neth J Sea Res 34:81-88

Becker DS (1988) Relationship between sediment character and sex segregation in English sole, Parophrys vetulus. Fish Bull US 86:517-524

Berghahn R, Ludemann K, Ruth M (1995) Differences in individual growth of newly settled 0-group plaice (Pleuronectes platessa L.) in the intertidal of neighbouring
Wadden Sea areas. Neth J Sea Res 34:131-138

Beutel TS, Beeton RJS, Baxter GS (1999) Building better wildlife-habitat models. Ecography 22:219-223

Bigelow HB, Schroeder WC (1953) Fishes of the Gulf of Maine. Fish Bull Fish Wildl Serv 53:276-283

Brodley CA, Lane T, Stough TM (1999) Knowledge discovery and data mining. Am Sci 87:54-60

Casterlin ME, Reynolds WW (1982) Thermoregulatory behavior and diel activity of yearling winter flounder, Pseudopleuronectes americanus (Walbaum). Environ Biol Fish 7: $177-180$

Chant RJ, Stoner AW (2001) Particle trapping in a stratified floof-dominated estuary. J Mar Sci 59: (in press)

Crawford RE, Carey CG (1985) Retention of winter flounder larvae within a Rhode Island salt pond. Estuaries 8:217-227

Derrick PA, Kennedy VS (1997) Prey selection by the hogchoker, Trinectes maculatus (Pisces: Soleidae), along summer salinity gradients in Chesapeake Bay, USA. Mar Biol 129:699-711

Efron B, Tibshirani R (1991) Statistical data analysis in the computer age. Science 253:390-395

Folk RL (1966) A review of grain size parameters. Sedimentology 6:73-93

Gibson RN (1994) Impact of habitat quality and quantity on the recruitment of juvenile flatfishes. Neth J Sea Res 32: 191-206

Gibson RN (1997) Behaviour and the distribution of flatfishes. J Sea Res 37:241-256

Gibson RN, Robb L (1992) The relationship between body size, sediment grain size and the burying ability of juvenile plaice, Pleuronectes platessa L. J Fish Biol 40:771-778

Gibson RN, Pihl L, Burrows MT, Modin J, Wennhage H, Nickell LA (1998) Diel movements of juvenile plaice Pleuronectes platessa in relation to predators, competitors, food availability and abiotic factors on a microtidal nursery ground. Mar Ecol Prog Ser 165:145-159

Hastie TJ (1991) Generalized additive models. In: Chambers JM, Hastie TJ (eds) Statistical models in S. Chapman \& Hall, New York, p 249-307

Hastie T, Tibshirani R (1990) Generalized additive models. Chapman \& Hall, London

Hires RI, Mellor GL (1988) Numerical model studies of circulation in the Hudson-Raritan estuary. In: NOAA Estuary of the Month Seminar Series, No. 9. Hudson/Raritan Estuary: issues, resources, status, and management. NOAA Estuarine Programs Office, Washington, DC, p 27-43

Howell PT, Molnar DR (1995) Inshore survey of juvenile winter flounder. Conn Dept Environ Protection, Final Rept No. F54R, Hartford, p 55-78

Jager Z, Kleef L, Tydeman P (1993) The distribution of 0group flatfish in relation to abiotic factors on the tidal flats in the brackish Dollard (Ems estuary, Wadden Sea). J Fish Biol 43:31-43

Keller AA, Klein-MacPhee G, Burns JS (1999) Abundance and distribution of ichthyoplankton in Narragansett Bay, Rhode Island, 1989-1990. Estuaries 22:149-163

Kuipers B (1973) On the tidal migration of young plaice (Pleuronectes platessa) in the Wadden Sea. Neth J Sea Res 6: 376-388

Kuipers BR (1975) On the efficiency of a two-metre beam trawl for juvenile plaice (Pleuronectes platessa). Neth $\mathrm{J}$ Sea Res 9:69-85

Kuipers B (1977) On the ecology of juvenile plaice on a tidal flat in the Wadden Sea. Neth J Sea Res 11:56-91

Kuipers BR, MacCurrin B, Miller JM, van der Veer HW, Witte JI (1992) Small trawls in juvenile flatfish research: their development and efficiency. Neth J Sea Res 29:109-117 
Legendre P, Legendre L (1998) Numerical ecology, developments in environmental modelling 20, 2nd edn. Elsevier, Amsterdam

Leopold MF, Van Damme CJG, van der Veer HW (1998) Diet of cormorants and the impact of cormorant predation on juvenile flatfish in the Dutch Wadden Sea. J Sea Res 40: 93-107

Livingston RJ (1982) Trophic organiziation of fishes in a coastal seagrass system. Mar Ecol Prog Ser 7:1-12

Livingston RJ (1984) Trophic response of fishes to habitat variability in coastal seagrass systems. Ecology 65:1258-1275

Livingston RJ (1988) Inadequacy of species-level designations for ecological studies of coastal migratory fishes. Environ Biol Fish 22:225-234

MacCall AD (1990) Dynamic geography of marine fish populations. Univ Washinton Press, Seattle, WA

Manderson JP, Phelan BA, Bejda AJ, Stehlik LL, Stoner AW (1999) Predation by striped searobin (Prionotus evolans, Triglidae) on young-of-the-year winter flounder (Pseudopleuronectes americanus Walbaum): examining prey size selection and prey choice using field observations and laboratory experiments. J Exp Mar Biol Ecol 242:211-231

Manderson JP, Phelan BA, Hilbert J, Stoner AW (2000) Predator-prey relations between age $1+$ summer flounder (Paralichthyes dentatus Linnaeus) and age-0 winter flounder (Pseudopleuronectes americanus Walbaum): predator diets, prey selection, and effects of sediment and vegetation. J Exp Mar Biol Ecol 251:17-39

Maravelias CD (1999) Habitat selection and clustering of a pelagic fish: effects of topography and bathymetry on species dynamics. Can J Fish Aquat Sci 56:437-450

Maravelias CD, Reid DG (1997) Identifying the effects of oceanographic features and zooplankton on prespawning herring abundance using generalized additive models. Mar Ecol Prog Ser 147:1-9

Mattila J, Bonsdorff E (1998) Predation by juvenile flounder (Platichthys flesus L.): a test of prey vulnerability, predator preference, switching behaviour and functional response. J Exp Mar Biol Ecol 227:221-236

McBride EF (1971) Mathematical treatment of size distribution data. In: Carver RE (ed) Procedures in sedimentary petrology. Wiley, New York, p 109-127

McIntyre AD, Eleftheriou A (1968) The bottom fauna of a flatfish nursery ground. J Mar Biol Assoc UK 48:113-142

Miller JM, Burke JS, Fitzhugh GR (1991) Early life history patterns of Atlantic North American flatfish: likely (and unlikely) factors controlling recruitment. Neth J Sea Res 27:261-275

Moles A, Norcross BL (1995) Sediment preference in juvenile Pacific flatfishes. Neth J Sea Res 34:177-182

Neuman MJ, Able KW (1998) Experimental evidence of sediment preference by early life history stages of windowpane (Scophthalmus aquosus). J Sea Res 40:33-41

Norcross BL, Muter FJ, Holladay BA (1997) Habitat models for juvenile pleuronectids around Kodiak Island, Alaska. Fish Bull 95:504-520

Norcross BL, Blanchard A, Holladay BA (1999) Comparison of models for defining nearshore flatfish nursery areas in Alaskan waters. Fish Oceanogr 8:50-67

Petitgas P (1998) Biomass-dependent dynamics of fish spatial distributions characterized by geostatistical aggregation curves. ICES J Mar Sci 55:443-453

Phelan BA (1992) Winter flounder movements in the inner New York Bight. Trans Am Fish Soc 121:777-784

Phelan BA (2000) Habitat associations in shallow water fish and crustaceans in estuaries of the northeastern US. PhD dissertation, Rutgers University, New Brunswick, NJ
Phelan BA, Goldberg R, Bejda AJ, Pereira J, Hagan S, Clark P, Studholme AL, Calabrese A, Able KW (2000) Estuarine and habitat-related differences in growth rates of youngof-the-year winter flounder (Pseudopleuronectes americanus) and tautog (Tautoga onitis) in three northeastern U.S. estuaries. J Exp Mar Biol Ecol 247:1-28

Phelan BA, Manderson JP, Stoner AW, Bejda AJ (2001) Size-related shifts in the habitat associations of young-ofthe-year winter flounder (Pseudopleuronectes americanus Walbaum): field observations and laboratory experiments with sediments and food. J Exp Mar Biol Ecol 257:297-315

Pihl L, van der Veer HW (1992) Importance of exposure and habitat structure for the population density of 0 -group plaice, Pleuronectes platessa L., in coastal nursery areas. Neth J Sea Res 29:145-152

Powell AB, Schwartz FJ (1977) Distribution of paralichthid flounders (Bothidae: Paralichthys) in North Carolina estuaries. Chesapeake Sci 18:334-339

Rejwan C, Collins NC, Brunner LJ, Shuter BJ, Ridgway MS (1999) Tree regression analysis on the nesting habitat of smallmouth bass. Ecology 80:341-348

Rijnsdorp AD, VanBeek FA, Flatman S, Millner RM, Riley JD, Giret M, DeClerck R (1992) Recruitment of sole stocks, Solea solea (L.), in the northeast Atlantic. Neth J Sea Res 29:173-192

Riley JD, Corlett J (1966) The numbers of 0-group plaice in Port Erin Bay, 1964-66. Annu Rep Mar Biol Stn Port Erin 78:51-56

Rogers SI (1992) Environmental factors affecting the distribution of sole (Solea solea (L.) within a nursery area. Neth J Sea Res 29:153-161

Scarlett PG (1991) Temporal and spatial distribution of winter flounder (Pseudopleuronectes americanus) spawning in the Navesink and Shrewsbury Rivers, New Jersey. New Jersey Dept Environ Protection Div Fish, Game Wildlife, Trenton

Scarlett PG, Allen RL (1992) Temporal and spatial distribution of winter flounder (Pleuronectes americanus) spawning in the Manasquan River, New Jersey. Bull NJ Acad Sci 37: $13-17$

Scott JS (1982) Selection of bottom type by groundfishes of the Scotian shelf. Can J Fish Aquat Sci 39:943-947

Sogard SM (1992) Variability in growth rates of juvenile fishes in different estuarine habitats. Mar Ecol Prog Ser 85: $35-53$

Sogard SM, Able KW (1992) Growth variation of newly settled winter flounder (Pseudopleuronectes americanus) in New Jersey estuaries as determined by otolith microstructure. Neth J Sea Res 29:163-172

Stehlik LL, Meise CJ (2000) Diet of winter flounder in a New Jersey estuary: ontogenetic change and spatial variation. Estuaries 23:281-391

Stoner AW (1980) Feeding ecology of Lagodon rhomboides (Pisces; Sparidae): variation and functional responses. Fish Bull 78:337-352

Stoner AW, Bejda AJ, Phelan BA, Manderson JP, Stehlik LS (1999) Behavior of winter flounder (Pseudopleuronectes americanus) during the reproductive season: laboratory and field observations on spawning, feeding, and locomotion. Fish Bull 97:999-1016

Swain DP, Morin R (1997) Effects of age, sex and abundance on the bathymetric pattern of American plaice in southern Gulf of St Lawrence. J Fish Biol 50:181-200

Swartzman G, Huang C, Kaluzny S (1992) Spatial analysis of Bering Sea groundfish survey data using generalized additive models. Can J Fish Aquat Sci 49:1366-1378

Swartzman G, Silverman E, Williamson N (1995) Relating 
trends in walleye pollock (Theragra chalcogramma) abundance in the Bering Sea to environmental factors. Can J Fish Aquat Sci 52:369-380

Timmons M (1995) Relationships between macroalgae and juvenile fishes in the inland bays of Delaware. MS thesis, University of Delaware, Lewes

Toole CL, Markle DF, Donohoe CJ (1997) Settlement timing, distribution, and abundance of Dover sole (Microstomus pacificus) on an outer continental shelf nursery area. Can J Fish Aquat Sci 54:531-542

van der Veer HW, Witte JIJ (1993) The maximum growth optimal food condition hypothesis - a test for 0-group plaice Pleuronectes platessa in the Dutch Wadden Sea. Mar Ecol Prog Ser 101:81-90

van der Veer HW, Ellis T, Miller JM, Pihl L, Rijnsdorp AD (1997) Size-selective predation on juvenile North Sea flat-

Editorial responsibility: Ron Kneib (Contributing Editor), Sapelo Island, Georgia, USA fish and possible implications for recruitment. In: Chambers RC, Trippel EA (eds) Early life history and recruitment in fish populations. Chapman \& Hall, London, p 279-303

Venables WN, Ripley BD (1997) Modern applied statistics with S-plus, 2nd edn. Springer-Verlag, New York

Walsh HJ, Peters DS, Cyrus DP (1999) Habitat utilization by small flatfishes in a North Carolina estuary. Estuaries 22: 803-813

Wennhage H, Gibson RN (1998) Influence of food supply and a potential predator (Crangon crangon) on settling behaviour of plaice (Pleuronectes platessa). J Sea Res 39:103-112

Witting DA, Able KW (1995) Predation by sevenspine bay shrimp Crangon septemspinosa on winter flounder Pleuronectes americanus during settlement: laboratory observations. Mar Ecol Prog Ser 123:23-31

Submitted: October 3, 1999; Accepted: May 8, 2000 Proofs received from author(s): February 27, 2001 